\title{
Inflammation-Angiogenesis Cross-Talk and Endothelial Progenitor Cells: A Crucial Axis in Regenerating Vessels
}

\author{
Michele M. Ciulla, Paola Nicolini, Gianluca L. Perrucci, \\ Chiara Benfenati and Fabio Magrini \\ University of Milan \\ Italy
}

\section{Introduction}

The normal cell is confined by its genetic program to a rather narrow range of morphofunctional characteristics within which it is nevertheless able to handle normal physiological demands (Kumar et al., 2011). A single cell, placed in an appropriate environment, contains, enclosed in its genome, sufficient information to generate a variety of differentiated cell types, whose spatial and temporal dynamics interact to form detailed morphological patterns (Geard and Wiles, 2005). Similarly, in multicellular organisms, it is the genetic program that establishes networks basics -including differentiation, functional hierarchy and interaction patterns- with each level in the system representing an increase in organizational complexity. Indeed the emergence from a single or few stem cells of multicellular organisms with a complex organization must be seen as a necessity in evolution since it alone can ensure an optimal use of resources (Furusawa and Kaneko, 2000). From such evolutionary perspective, the development of a cardiovascular system in complex organisms fulfills the need for transport of nourishment, oxygen and metabolic waste as well as the need for communication between distant districts.

All closed biological systems facing the external environment, whatever their level of complexity, are characterized by the ability to maintain a stable, constant condition by regulating themselves and the internal environment. In the early $19^{\text {th }}$ century Cannon (Cannon, 1926) defined this property "homeostasis", from the Greek: öhotos, hómoios, "similar" and oráors, stásis, "standing still". This condition of relative equilibrium grants the biological system a certain degree of independence from the environment and enables what we call life.

Any change, either decremental or incremental, in the internal/external environment of the cell/organism such that it requires an active response from the cell/organism can be termed demand. In the case of complex organisms demands are met by the functional reserve of the cell/tissue/organ. The functional reserve is involved in the process of adaptation by which a cell/organism acquires morphofunctional features that allow it to better fit in with the changed environment and thus attain a new equilibrium (Figure 1). Adaptation is driven by the genetic program, via the activation of appropriate subsets of genes, and is influenced by the qualitative and quantitative characteristics of the demand such as its nature, intensity and duration. Adaptation can be considered to include both plasticity and adaptability. Plasticity is 
the ability to express a broad variety of phenotypes in response to environmental changes and is at a maximum during embryogenesis and early extrauterine life. The term adaptability could instead be applied to the (more limited) process of adaptation which occurs in adult life and varies between organs and species. In complex organisms two points deserve particular mention. First, it should be remarked that, since complex organisms possess cognitive functions, demands can be not only physical but also mental or emotional, and that no line can be drawn between body and mind. Second, the functional hierarchy of complex organisms is paramount in allocating functional reserve where it is needed so that priorities can be established in the distribution of the available resources.

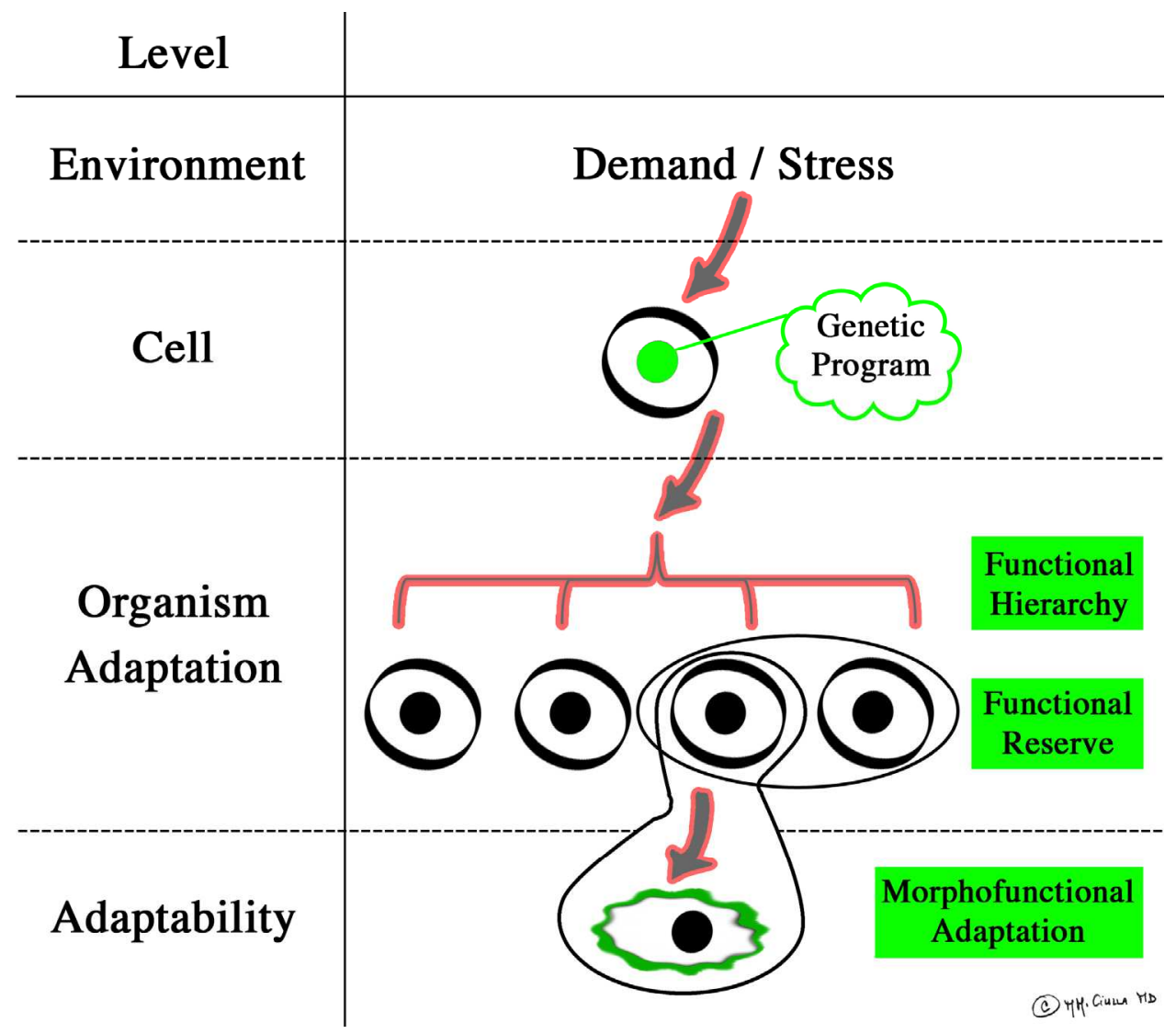

Fig. 1. Genetic programming and functional hierarchy

Schematic representation of the interplay between environmental demands and the geneticdriven adaptation process in adult life. In complex organisms genetic programming is paramount in allocating functional reserve where it is needed. Adaptation is the response to environmental demands and involves the acquisition by a cell/organism of morphofunctional features that allow it to better fit in with the changed environment. Adaptation includes plasticity and adaptability. During development plasticity is progressively replaced by adaptability. 
Thus, the adaptation process -whether be it grounded in plasticity or adaptability- is determined by the genetic program. Since the genetic program is finite so is also the functional reserve, and there is necessarily an intrinsic limit to adaptation. However, this limit is extremely variable from subject to subject because each organism possesses a peculiar genotype and thus a unique functional reserve.

It must be underscored that there is a lifelong interplay between genome and environment, i.e. the genome-driven adaptation process is continuously called upon to buffer environmental changes throughout the life of an individual. What happens then when the functional reserve is inadequate per se and/or in relation to the characteristics of the demand? There arises a condition which is currently classified as stress and appears to be more common than is generally believed, although it is not formally considered a disease. In fact stress may cause cell injury but a disease can be recognized as such only when cell injury leads to functional deficits in the organism and to the occurrence of signs and/or symptoms. Hence, the notion of disease has very much to do with communication. It can be conceived as communication at multiple levels of complexity: from cell to neighbouring cells, from organs to organism and, finally from organism to organism. The latter is the apex of the communication process and corresponds to what is normally witnessed in everyday life when the patient attends the doctor's office.

In summary, it is the balance between genetically-determined functional reserve and environmental changes that delineates the fuzzy boundary between physiology and pathology, between what we define a current and an extra demand and, ultimately, between what we define health and disease. In complex organisms with an evolved circulatory system, the role of the circulation as a dynamic interface between blood and tissues implies that it is continuously challenged by noxious stimuli of different kinds (mechanical, chemical, biological). Thus the circulatory system plays a key role in communicating stress at a distance and in responding to it through the vascular changes that characterize inflammation, even by replacing its own damaged endothelial cells. This is the conceptual basis of vascular homeostasis and the reason why in organisms with a circulatory system inflammation acts as a bridge between environment (demand) and genome (response).

\section{The circulation of blood and its constituents: an evolved system of transport and communication}

There are about 100 trillion cells in the human body, a number that is about ten thousand times greater than the number of human beings on Earth. Even though they are an awesome multitude all these cells can communicate directly or indirectly with each other. Every single cell needs to receive nourishment, replenish oxygen and remove waste in order to survive and work properly. It must also be able to inform other cells about its fate, the changes it experiences, the answers it provides to stimuli and, in general, the actions it intends to take. Successful cell functioning therefore requires the existence of an excellent "communication route" that enables cells to exchange information with the external environment, and with distant cells via humoral signaling. This route is the circulatory system, which is a perfect model of a dynamic and well-organized highway. Consistently with its function, it is composed of an extensive network of vessels: De Witt (2005) has calculated that blood vessels from an adult would circle the earth twice if placed end to end (DeWitt, 2005). Busy but efficient, the circulatory system consists of two basic elements: the 
vessels (composed by endothelium and connective tissue) and the blood. It is a highly dynamic system which is always "turned on" and ready to respond to the changing demands of the organism. Given the dynamic nature of the vascular system, vascular injury requires rapid repair and this means that "spare parts" must be readily available. Later in this chapter we will see which are the main players in vascular turnover and which are the cellular and molecular processes involved in the repair of vascular damage.

\subsection{Open and closed circulatory systems}

With very few exceptions, all coelomates (by the broadest definition, every organism with a fluid-filled cavity) possess a circulatory system (Ruppert and Carle, 1983). The walls of the blood vessels are made of a layer of epithelial cells which in most invertebrates forms part of the coelomic lining (called mesothelium or peritoneum); the mesothelium lining the blood vessels contains myofibrils (myo-epithelium) whose contractility determines the flow of blood. In vertebrates and some invertebrates, blood vessels are lined by a non-muscular endothelium and are surrounded by a separate muscle cell layer. Blood vessels can form two different types of circulatory systems: closed, e.g. in chordates and annelids, or open at both ends, e.g. in arthropods such as insects, and mollusks. In the former case, the body fluid is contained within two separate compartments, one inside the lumen of the circulatory system (blood), the other inside the coelom (coelomic fluid). In the latter case, there is a single compartment filled with a body fluid called hemolymph. Blood, coelomic fluid and hemolymph contain dispersed cells, generally termed blood cells or hemocytes (Ratcliffe and Rowley, 1979). Contractile blood vessels, such as the dorsal vessel/heart in insects, are suspended within the hemolymphatic space and cause a streaming motion of the hemolymph by means of rhythmic contractions. Evolution well illustrates how an increase in complexity is always paralleled by an increase in needs and thus requires the establishment of appropriate structures to support them. A closed vascular system, under neural control, is consistent with the functional hierarchy of complex organisms, since it allows a fine-tuned modulation of the blood flow to allocate resources (nutrients, oxygen) to the body districts that most require them.

\subsection{Embryo vasculogenesis}

The development of the circulatory system is a key event during embryogenesis in many animal species. The process of vasculogenesis involves the differentiation of local mesodermal precursors into vascular and endothelial cells (ECs). These are clustered in blood islands whose growth and fusion leads to the formation of a primary vascular plexus (Carmeliet, 2000; Risau and Flamme, 1995; Timmermans et al., 2009). After the onset of the blood circulation, the yolk sac capillary network differentiates into an arteriovenous vascular system (Risau et al., 1988). The integral relationship between the elements that circulate in the vascular system (the blood cells) and the cells that are mainly responsible for the vessels themselves (the endothelial cells) is reflected by the composition of the embryonic blood islands. In fact the cells which are destined to generate hematopoietic cells are located in the center of the blood islands and are termed hematopoietic stem cells (HSCs) while endothelial progenitor cells (EPCs), or angioblasts, can be found at the periphery of the blood islands. In addition to this spatial association, HSCs and EPCs share certain antigenic markers, including Flk-1, Tie-2, Sca-1 and CD34, which will be discussed later in greater detail. On the basis of such embryological and molecular data there is evidence for a close developmental relationship between these two types of progenitor cells, 
thus EPCs and HSCs have been considered to derive from a putative common precursor, termed hemangioblast (Choi et al., 1998; Flamme and Risau, 1992; Weiss and Orkin, 1996).

For a long time the existence of a common precursor for both hematopoietic and endothelial cells was believed to be restricted to embryonic development but recent studies have identified a postnatal hemangioblast. Over recent years, much attention has focused on bone marrow (BM) stem cell potentiality. It has been reported that the bone marrow contains cells termed multipotent adult progenitor cells (MAPCs), which, at a single-cell level, can differentiate into a large number of cell types, including endothelial cells (Reyes et al., 2002). Bone marrow-derived EPCs originate from CD34+ stem cells, which are able to differentiate via separate pathways not only in endothelial cells but also in erythrocytes, thrombocytes and various lineages of leukocytes.

It is possible that circulating EPCs mobilized from the bone marrow are in fact progenitor or stem cells with a broader differentiation potential which is directed towards the formation of endothelial cells at sites of neovascularization, where the microenvironment is adequate for such process to occur (Asahara et al., 1997; Peichev et al., 2000). Indeed, a decade ago, two groups reported that human $\mathrm{CD} 34+$ cells isolated from circulating peripheral blood (PB), umbilical cord blood (UCB) and BM, could differentiate into ECs in vitro and in vivo in mouse models, thereby contributing to neoendothelialization and neovascularization in the adult organism (Asahara et al., 1997; Shi et al., 1998).

\subsection{Stemness and the hemangioblast}

As we have seen, stem cells have a key role in the setting of both embryonic and postnatal vasculogenesis. The two main players on stage are the hemangioblast and the EPC. The hemoangioblast is a pluripotent stem cell that is able to differentiate into cells belonging to the hemopoietic lineage and into EPCs. The EPC is a multipotent stem cell that can differentiate into various cell types including vessel-lining endothelial cells. Hemoangioblast and EPC are distinguished on the basis of a number of characteristics, including the developmental stage in which they are identified, their tissue localization, their molecular profile and their properties in vitro. Still, as new information is acquired and as experimental techniques are refined, the classification of stem cells is becoming less clear-cut and much more complex. Indeed a review by Blau and colleagues (Blau et al., 2001) endorses the pioneering view that a stem cell should not be considered a specific cellular entity but rather a biological function which can be taken on by numerous cell types expressing different genes. Traditionally, stem cells have been regarded as undifferentiated cells capable of self-renewal and production of a large number of differentiated progeny, with a sharp distinction being made between embryonic and adult stem cells. According to a large body of in vitro and in vivo evidence only embryonic stem cells (ES) were believed to be pluripotent -i.e. capable of differentiating into a wide range of cell types. Their high degree of plasticity fitted in well with the notion that maximum "flexibility" is required during the early stages of development, when a variety of body tissues are in the process of being formed. Adult stem cells were thought to exhibit a limited differentiative potential- i.e. to be able to differentiate exclusively into cells of the specific tissue in which they resided. This idea was supported by several examples of tissuespecific regeneration: the proliferation of liver cells after surgical removal of part of the liver, the production of blood elements by transplanted hematopoietic stem cells after chemo- or radio-induced $\mathrm{BM}$ ablation, the existence of satellite cells that repair damaged skeletal muscles, the participation of keratinocyte precursors in the healing of skin wounds. 
However, it is increasingly recognized that adult stem cells have a broader regenerative potential than was originally supposed, and that it is probably involved not only in the response to tissue injury but also in physiological tissue homeostasis. BM-derived cells have been reported to yield not only blood cells but also cells belonging to the brain, liver and heart. Stromal cells in the BM, other than HSC, have been found to give rise to a number of different cell types. Going one step further, even highly specialized cells such as muscle cells and central nervous system cells have been shown to be able to contribute to the replenishment of the blood. It is therefore speculated that adult stem cells possess a significant amount of plasticity which can be channelled along diverse differentiation pathways by the interactions they establish with the environment. Indeed, resorting once again to the "highway" metaphor, the circulatory system can be envisioned as the route through which stem cells gain access to all districts of the body. It has been documented experimentally that BM-derived cells enter different organs such as the heart, brain, skeletal muscle, and liver (Bittner et al., 1999; Brazelton et al., 2000; Ciulla et al., 2007c; Gussoni et al., 1999; Jackson et al., 1999; Krause et al., 2001; Lagasse et al., 2000; Mezey et al., 2000). The recruitment of stem cells from the circulation into a specific organ would be brought about by homing signals, as has been described for the homing of leukocytes (Butcher, 1991). Likewise, the behavior of the stem cells - in terms of generative potential- would then be determined by the surrounding microenvironment, including the extracellular matrix (Hay, 1991), the local milieu (Studer et al., 2000) as well as growth and differentiation factors. Stem cells would thus be stimulated to assume morphologies and functions typical of the new environment in which they have migrated. Therefore, stem cell plasticity coupled with the availability of a route connecting different compartments of the organism, explains how stem cells residing in one tissue would be able to contribute to the regeneration of distal tissues.

In summary, the concept of stemness should be conceived as a highly dynamic one, with no fixed tissue-specific boundary either in the localization or in the differentiation of stem cells.

\subsubsection{The hemangioblast}

It has already been mentioned that the formation of blood islands in the extraembyronic yolk sac marks the onset of hematopoiesis and vasculogenesis in the developing embryo. These blood islands derive from aggregates of mesodermal cells that colonize the presumptive yolk sac. In about 12 hours, the central cells within these clusters give rise to embryonic hematopoietic cells while the peripheral cells differentiate into endothelial cells which form the first vascular structures that surround the inner blood cells (Wagner, 1980). The close developmental association of the hematopoietic and endothelial lineages within the blood islands has led to speculate that they arise from a common precursor, the hemangioblast (Murray, 1932; Sabin, 1920; Wagner, 1980). This hypothesis has gained most support from the observation that the hematopoietic and endothelial lineages share the expression of a number of different genes (Anagnostou et al., 1994; Asahara et al., 1997; Fina et al., 1990; Kabrun et al., 1997; Kallianpur et al., 1994; Millauer et al., 1993; Yamaguchi et al., 1993; Young et al., 1995). Moreover, recent gene-targeting experiments demonstrating that a functional Flk-1 receptor tyrosine kinase is required for the development of the blood islands are consistent with the notion that these lineages derive from a common precursor (Shalaby et al., 1997; Shalaby et al., 1995). However, there is still no definite proof of the existence of the hemoangioblast. Past studies aimed at identifying and characterizing the putative hemangioblast have been hampered by difficulties in accessing the embryo prior to 
the establishment of the blood islands and by the limited number of cells present at this stage of development. Differentiation of embryonic stem (ES) cells to hematopoietic and endothelial cells in culture provides an alternative approach for investigating these early commitment steps since both cellular and molecular analyses have documented that the sequence of events giving rise to these lineages is similar in vitro and in the normal mouse embyo (Keller et al., 1993; Keller, 1995; Nakano et al., 1994; Risau et al., 1988; Vittet et al., 1996; Wiles and Keller, 1991). Indeed, using this in vitro model, it has recently been shown that embryoid bodies (EBs) generated from ES cells allowed to differentiate for 3-3.5 days contain a unique precursor population with both primitive and definitive hematopoietic potential (Kennedy et al., 1997). When cultured in the presence of vascular endothelial growth factor (VEGF), c-kit ligand (KL) and conditioned medium from an endothelial cell line, D4T, these precursors form colonies consisting of immature or blast-like cells that express a number of genes common to both the hematopoietic and endothelial lineages, including tal-1/SCL, CD34 and the VEGF receptor, flk-1 (Kennedy et al., 1997). The responsiveness to VEGF of these embryonic precursors together with the gene expression pattern of their blast cell progeny suggests that this population could have the potential to generate cells of the endothelial lineage in addition to hematopoietic precursors (Choi et al., 1998).

\section{Cellular identity, a dynamic concept}

Until a few decades ago, many dogmas of cell biology had not yet been dismantled; among them was the idea that cells might not have an alternative fate after maturation according to their specific identity.

The effects of nuclear transfer to enucleated oocytes in adult cells (Gurdon, 1960) have experimentally shown that the mechanisms that regulate cell identity follow rules, bound to processes of genetic reprogramming, which are still unclear today. There are two well-known processes by which cells are able to turn into other cell types: transdifferentiation, i.e. the direct conversion from one cell type to another, and dedifferentiation, i.e. the reversion to a less-differentiated cell type and the subsequent maturation to a different lineage.

After Dolly the sheep (Campbell et al., 1996), cell biology moved under the spotlight and there arose within the scientific community questions which have still not found exhaustive answers. Cell identity, which had so far been considered a rigid and durable characteristic involving a one-way process from precursor to mature cell, was shown to exhibit not only intrinsic plasticity (Scadden, 2007) but also a large degree of adaptation depending on the interplay between genome and microenvironment.

In fact it was demonstrated that mature cells are able to switch not only their functional phenotype but also their gene expression profile into that of stem cells, thereby acquiring pluripotent plasticity. Such findings yielded several questions: can all somatic cells dedifferentiate? What kind of epigenetic events are able to reverse the fate of a cell which is already committed and in what order can they do so? Factors that can reverse the fate of the cells are only endogenous or can they be exogenous too? As far as regenerative medicine is concerned, the latter question is the most important, since the application of potential drug treatments that can revert a pool of cells into stem cells capable of regenerating damaged tissues in the setting of injury or disease holds great promise.

In the field of regenerating vessels the central issue is: what kind of cells are able to repair vascular damage? The answer to this apparently straightforward question - i.e. EPCs - leads 
us into a topic fraught with controversy. In fact the identity of EPCs from both a molecular and technical standpoint is still open to discussion and experimentation. It would therefore be helpful to find biological markers of progenitor cells in order to validate a reproducible method for the enumeration and distinction of EPCs from circulating endothelial cells (CECs). Different approaches have been used to detect these cells, including in vitro culture, magnetic bead separation and fluorescence microscopy, immunocytochemistry and flow cytometry (Bull et al., 2003; Del Papa et al., 2004; George et al., 1993; Goon et al., 2006; Mancuso et al., 2001; Mutunga et al., 2001; Nakatani et al., 2003), each having specific strengths and limitations.

\subsection{EPC Identity}

Numerous markers of EPC lineage have been proposed in the literature, subcategorized into stem cell makers (such as CD34, CD133, CD45, and c-kit) and endothelial-like markers (such as VEGF receptor (VEGFR), CD31, CD146, and von Willebrand factor) (Hristov et al., 2003a; Timmermans et al., 2009). However, the precise definition of what constitutes an EPC is the subject of an extensive debate (Asosingh et al., 2009; Diller et al., 2008). At present, the only EPC phenotype based on surface antigenic markers that provides strong and reproducible correlations across multiple studies on vascular damage and cardiovascular risk is CD34+/VEGFR+ (Fadini et al., 2008). An additional phenotype that has recently been employed in the literature involves the inclusion of CD133 as a secondary stem cell marker (Friedrich et al., 2006); however, Timmermans et al. have recently questioned its utility as an EPC marker (Timmermans et al., 2009; Timmermans et al., 2007). Notably, the intersection of the CD34+/CD133+ and CD34+/ VEGFR+ cell phenotypes (i.e., CD34+/CD133+/ VEGFR+ cells) is known to be extremely rare (Fadini et al., 2008).

Many investigators have identified or designated putative circulating EPCs (CEPCs) with flow cytometry using a single surface marker such as CD34 or CD133, or various combinations of surface markers, which has actually resulted in a complicated list of putative CEPC immunophenotypes both in humans and mice. Most of the surface marker combinations used in flow cytometry studies included the marker CD34 and VEGFR-2, because initial studies in the field had reported that CD34+ and VEGFR-2+ cells purified from various sources like $\mathrm{UCB}, \mathrm{PB}$ and $\mathrm{BM}$ were able to generate ECs in vitro, suggesting that CD34+ cells contain CEPCs (Asahara et al., 1997; Bompais et al., 2004; Shi et al., 1998). One specific subset of CD34+ cells, designated as CD34+VEGFR-2+CD133+ cells, is widely accepted to correspond to 'true CEPCs' in humans but yet these cells were never directly tested for their ability to generate new ECs in vitro or in vivo, which is essential to validate CD34+VEGFR-2+CD133+ cells as true CEPCs (Bertolini et al., 2006; Kondo et al., 2004; Peichev et al., 2000). Recently, however, Case et al. , using in vitro hematopoiesis assays, reported for the first time that isolated human UCB or mobilized adult PB CD34+VEGFR$2+\mathrm{CD} 133+$ cells in fact represent an enriched population of CD45+ hematopoietic precursors, but that CD34+VEGFR-2+CD133+ did not contribute to the formation of ECs in vitro (Case et al., 2007). Similarly, CD34+CD45+CD146+ cells previously considered to be CEPCs, were not directly assayed in vitro, nor in vivo for their ability to contribute to newly formed endothelium, and thus, it is difficult to know whether this cell type acts as a true CEPC (Delorme et al., 2005). Therefore, the scientific foundation for using CD34+ plus variable combinations of surface markers remains elusive. Moreover, the use of these diverse combinations to define a singular entity (the CEPC), makes the significance of flow cytometry studies difficult to interpret, creates obstacles to the direct comparison of data 
between laboratories, and may result in discrepancies in the interpretations of study results among different laboratories. Therefore, investigators should strongly consider that any 'putative' CEPC, whatever its phenotype, be carefully assessed by validating its postnatal endothelial differentiation capacity in vitro and in vivo. An effective way of doing so is to test the ability of CEPCs to form endothelial colonies in vitro (Ciulla et al., 2006) or actual vessels in vivo (Ciulla et al., 2007b; Ciulla et al., 2007c). However, even the latter approaches pose a series of challenges because they involve a number of variables such as the exact combination of growth factors to which the cells are exposed in vitro and, in vivo, the type of animal model used, its genetic background and the nature of the angiogenic stimulus applied. Furthermore, a potential limitation of single-cell clonal assays is that a cell may behave differently according to whether it is isolated or in the presence of other cells, and thus transplanting or culturing a single cell may not be an appropriate EPC assay, and the presence of supportive cells with a different phenotype or function may be required.

In summary, one of the greatest problems to date in the field of EPC biology is the lack of a unique marker, or combination of markers, that solely identifies the rare CEPCs in humans (between $\mathbf{0 . 0 1 \%}$ and $\mathbf{0 . 0 0 0 1 \%}$ of peripheral mononuclear cells) (Shaffer et al., 2006). As Blau and colleagues (Blau et al., 2001) very appropriately point out, this obstacle may be technical or indeed purely biological- i.e. specific molecular markers for stem cells are not available either because they have not yet been discovered or because they simply do not exist.

\section{The endothelium: More than a lining}

The endothelium is a key component of the vascular system, being strategically located to provide a physical interface between blood and tissues. Far from being an inert layer of "nucleated cellophane" (Chen et al., 2008; Cines et al., 1998; Galley and Webster, 2004) it participates in a number of physiological processes such as the transfer of biologically active molecules to the underlying interstitium and cells, the selective transmigration of cells in and out of the bloodstream, the modulation of vasomotor tone and the regulation of hemostasis/coagulation (Chen et al., 2008; Cines et al., 1998; Galley and Webster, 2004; Hunting et al., 2005; Mikirova et al., 2009). In an average adult it contains ten trillion (1013) cells, weighs about $1 \mathrm{~kg}$ and covers a surface area of approximately $7 \mathrm{~m}^{2}$ (Cines et al., 1998; Galley and Webster, 2004; Lin et al., 2000). It has traditionally been considered a rather static structure with little turnover (0.1\% replications per day) (Cines et al., 1998), but over the last two decades its highly dynamic nature is being increasingly recognized (Dignat-George and Sampol, 2000; Mikirova et al., 2009). Indeed the endothelium is continuously exposed to different kinds of noxious stimuli (mechanical, chemical, biological) that damage endothelial cells and injured endothelial cells need to be replaced in order to guarantee structural/functional vascular integrity and prevent atherosclerotic disease. Initially endothelial repair was believed to occur exclusively through the proliferation and migration of mature endothelial cells surrounding the lesion. However, these are terminally differentiated cells with low proliferative potential (Caplan and Schwartz, 1973; Haudenschild and Studer, 1971; Haudenschild and Schwartz, 1979; Hristov et al., 2003a; Jujo et al., 2008; Kunz et al., 1978; Malczak and Buck, 1977; Schwartz et al., 1980; Schwartz et al., 1981; Schwartz et al., 1975; Taylor and Lewis, 1986; Tongers et al., 2010) and it was reasonable to suppose that an alternative mechanism would be required for efficient endothelial regeneration. Research conducted along this line provided growing evidence 
that a crucial role in endothelial turnover is played by EPCs (Asahara et al., 1999; Asahara et al., 1997; George et al., 2011; Hristov et al., 2003a; Hunting et al., 2005; Jujo et al., 2008; Mikirova et al., 2009; Peichev et al., 2000; Tongers et al., 2010). These are BM-derived cells that can be found in the peripheral blood and have properties similar to those of embryonic hemangioblasts, being able to circulate, proliferate and differentiate into mature endothelial cells (Asahara et al., 1999; Asahara et al., 1997; Dignat-George and Sampol, 2000; George et al., 2011; Hristov et al., 2003b; Jujo et al., 2008; Peichev et al., 2000). In particular, they are mobilized from the BM into the circulation, travel to the site of vessel damage (a process known as recruitment or homing) and integrate into the endothelial monolayer to substitute damaged cells (Asahara et al., 1999; Asahara et al., 1997; George et al., 2011; Hristov et al., 2003b; Hunting et al., 2005; Jujo et al., 2008; Tongers et al., 2010). It is also becoming clear that EPCs do not merely have a direct, structural function -producing the "hardware" of the vessel -but also an important indirect, paracrine role, behaving as "cytokine factories"- i.e. they secrete proteins (growth factors, chemokines, cytokines) that have a variety of proangiogenic actions including the recruitment of additional EPCs and the suppression of apoptosis as well as the activation of "resident" EPCs (George et al., 2011; Jujo et al., 2008; Rehman et al., 2003; Tongers et al., 2010). As far as the latter are concerned, emerging data points to the presence of in situ EPCs, embedded within the vessel wall, that may aid in vascular repair, although their existence is still a matter of controversy (Ingram et al., 2005; Jujo et al., 2008; Torsney and Xu, 2011).

Animal studies have extensively demonstrated the involvement of BM cells in tissue regeneration after vascular damage. In a rat model of myocardial cryodamage it has been shown that labelled donor rat BM mononuclear cells (BM-MC) injected peripherally through the femoral vein were found after one week in the injured myocardium (Ciulla et al., 2003) in a number proportional to the size of the infarcted area (Ciulla et al., 2004) and were located within small early-stage vessels (Ciulla et al., 2007b). Similarly, in a rat model of myocardial ischemia induced by coronary artery ligation, human CD34+ cells injected intravenously were reported to infiltrate the infarcted zone within 48 hours and form capillaries of human origin after two weeks, improving echocardiographically-assessed left ventricular function (Kocher et al., 2001). Asahara and colleagues described the incorporation of BM-derived EPCs into sites of active angiogenesis one week after surgically-induced hindlimb and myocardial ischemia in a seminal work on BM transplant (BMT) murine models (Asahara et al., 1999; Asahara et al., 1997). Likewise, in a mouse model of hindlimb ischemia intravenous human EPCs were integrated into limb vessels at two weeks, significantly increasing blood flow at a Doppler evaluation. "Urbich C, Heeschen C, Aicher A, Dernbach E, Zeiher AM, Dimmeler S (2003) Relevance of monocytic features for neovascularization capacity of circulating endothelial progenitor cells. Circulation 2003 18;108(20):2511-6." In murine models of wire-induced arterial injury (carotid and femoral artery denudation), EPCs from donor mice were detected within the neoendothelium after two weeks (Ii et al., 2006; Urao et al., 2006). In a canine BMT model it was reported that a synthetic graft of the descending thoracic aorta was coated with endothelial cells derived from the donor three months post-angioplasty (Shi et al., 1998). With regard to humans, Lin and colleagues (Lin et al., 2000) investigated BMT recipients who had received gender-mismatched transplants and identified in the peripheral blood a small population of highly proliferative donor-derived cells, expanding more than a 1000fold after one month in culture. 


\section{Inflammation-angiogenesis cross-talk}

Inflammation is the body's protective response to noxious stimuli of different kinds (mechanical, chemical, biological). It has the purpose to dilute, circumscribe or destroy the injurious agent, and to promote the healing process. In complex organisms with a circulatory system, the distinctive feature of inflammation is a vascular reaction characterized by changes in the caliber and permeability of blood vessels (Kumar et al., 2011). Angiogenesis is closely related to inflammation and the endothelial cell lies at the very core of this association (Rajashekhar et al., 2006). In fact, activated inflammatory cells (macrophages, T cells) secrete Interleukin-1 (IL-1) and Tumoral Necrosis Factor $\alpha$ and $\beta$ (TNF) which stimulate the production of VEGF from the endothelium (Naldini and Carraro, 2005). VEGF, in turn, is a major proangiogenic factor with a number of effects on endothelial cells. Originally discovered as a potent and rapid inducer of vascular permeability (Vascular Permeability Factor, VPF) (Senger et al., 1983), it was then found to have a modest mitogenic effect on mature endothelial cells (Keck et al., 1989; Leung et al., 1989; Plouet et al., 1989) and finally it was shown to be an important participant in the regulation of EPC kinetics (Asahara et al., 1999; Olsson et al., 2006). Specifically, VEGF is believed to promote the mobilization of EPCs from the BM into the circulation by a) stimulating BM EPC proliferation b) providing a chemoattractive gradient for EPC migration towards the site of injury and c) modulating the BM-blood barrier, by increasing its permeability and modifying the expression of adhesion molecules (Asahara et al., 1999). VEGF is a dimeric glycoprotein of approximately $40 \mathrm{kDa}$ whose actions on vascular and progenitor endothelial cells are mainly mediated by the VEGFR-2 (Homsi and Daud, 2007; Olsson et al., 2006; Schabbauer et al., 2007). This is a tyrosine kinase containing in its cytoplasmic domain 19 tyrosine residues which are in part phosphorylated upon activation by receptor ligands and function as specific docking sites for molecules that initiate cytoplasmic signaling cascades (Olsson et al., 2006; Schabbauer et al., 2007). In particular, it has been shown that both Early Growth Response Protein-1 (EGR-1) and Nuclear Factor of Activated T cells (NFAT) are transcription factors involved in VEGF-mediated gene induction in endothelial cells (Schabbauer et al., 2007; Schweighofer et al., 2007). Matrix metalloproteinases (MMPs), a group of proteolytic enzymes which degrade the extracellular matrix (ECM), also appear to be involved in the mobilization of EPCs. Recently, a cross-talk between VEGF and MMPs has been suggested, with VEGF activating MMPs to favor the release of EPCs from the BM stroma and MMPs rendering available VEFG sequestered in the ECM (Ebrahem et al., 2010). VEGF is likewise produced by inflammatory cells (macrophages, neutrophils, $\mathrm{T}$ cells), consistently with the known redundancy of the cytokine system. It has been proposed that VEGF from different sources (endothelial and non-endothelial) may have different functional significance: endothelial VEGF seems to take part in an autocrine loop that conveys survival signals to the endothelium while paracrine VEGF is considered the main contributor to the angiogenic cascade (Lee et al., 2007).

Finally, it is important to remark that VEGF also acts on inflammatory cells: it is capable of recruiting macrophages, drive $\mathrm{T}$ cell differentiation towards a proinflammatory Th1 phenotype, and stimulate the production of IL- 1 and TNF by peripheral blood mononuclear cells (Angelo and Kurzrock, 2007; Mor et al., 2004; Naldini and Carraro, 2005; Noonan et al., 2008). Thus the inflammatory process is marked by an extensive bidirectional communication between the endothelium and inflammatory cells, via cytokines and growth factors, which establishes an inflammation-angiogenesis cross-talk. 


\subsection{Effects of C reactive protein on EPCs}

Within the scenario of inflammation-angiogenesis the role of $C$ Reactive Protein (CRP) on EPCs remains as yet uncertain and deserves a brief discussion. CRP has long been recognized as an acute phase protein whose plasma levels increase significantly (up to 1000fold) during systemic inflammation (Calabro et al., 2009). In such context it is synthesized by the liver in response to IL-6, IL-1 and TNF, and is a key component of innate immunity (Calabro et al., 2009; Li and Fang, 2004; Slevin and Krupinski, 2009). However, it is now acknowledged that CRP is also produced within the vascular wall at the site of inflammation. In vitro models have demonstrated that CRP is secreted by human coronary artery muscle cells after stimulation with cytokines (Calabro et al., 2003), by human aortic endothelial cells after stimulation with macrophage-conditioned medium (Venugopal et al., 2005) and by human brain endothelial microvessel cells following oxygen-glucose deprivation (Slevin et al., 2010). An in vivo study in patients with coronary artery disease (CAD) undergoing percutaneous coronary intervention (PCI) showed that CRP levels distal to the target lesion were higher than proximal levels and that CRP levels in coronary sinus blood increased in a time-dependent manner after stenting, consistently with the hypothesis of a local production of CRP (Inoue et al., 2005).

Moreover, it was found that CRP levels were higher in patients with unstable than stable angina and that the transcardiac CRP gradient at 48 hours after PCI was predictive of latelumen loss due to neointimal thickening (Inoue et al., 2005). Similarly, elevated preprocedural plasma CRP predicted restenosis after stenting (Hong et al., 2005) in one study and ergovine-induced coronary vasospasm during coronary angiography in another (Hung et al., 2005). Taken together these data provide evidence that CRP is a useful index of the "activity" of the atherosclerotic process. In fact atherosclerosis is no longer considered a mere lipid storage disease, stemming from the passive accumulation of lipids within the artery wall, but a chronic inflammatory disease which involves inflammation at all stages, from initiation to progression and, eventually, plaque rupture (Calabro et al., 2009; Paoletti et al., 2004). This is the reason why high-sensitivity CRP (hs-CRP)- i.e. the low CRP concentrations found in the peripheral blood in the absence of overt inflammation - has gained ample consensus in the evaluation of cardiovascular risk. Indeed hs-CRP is a stronger predictor of cardiovascular events - such as CAD, stroke, PAD and sudden cardiac death- than LDL cholesterol, and it adds prognostic value to the Framingham score (Ridker, 2001; Slevin and Krupinski, 2009).

It seems therefore established that there is a relationship between CRP and atherogenesis, but the role of CRP as an innocent bystander or active participant is still an unsettled and highly debated question (Calabro et al., 2009; Genest, 2010; Kushner et al., 2010; Lee et al., 2007; Slevin and Krupinski, 2009; Verma et al., 2004). According to several authors, CRP has a direct proatherogenic effect by exercising a wide spectrum of detrimental actions on both vessel wall cells and EPCs (Calabro et al., 2009; Li and Fang, 2004; Slevin and Krupinski, 2009; Verma et al., 2004). As far as mature endothelial cells are concerned it would a) decrease the expression and activity of nitric oxide synthase, causing endothelial dysfunction, b) increase the expression of surface adhesion molecules such as Vascular Cell Adhesion Molecule-1 (VCAM-1), Intercellular Adhesion Molecule-1 (ICAM-1) and selectins, favouring the recruitment of mononuclear cells, and c) induce the expression of oxidized LDL receptor, promoting lipid accumulation (Calabro et al., 2009; Verma et al., 2004). Macrophages and vascular smooth muscle cells (VSMCs) would also be involved, the former being stimulated to phagocyte oxidized low density lipoproteins (LDLs), the latter 
being induced to proliferate and migrate towards the intima (Calabro et al., 2009; Verma et al., 2004). With regard to EPCs, CRP has been shown to reduce their survival, differentiation and migration, thus impairing a crucial component of vascular integrity and regeneration (Verma et al., 2004).

However, when healthy subjects with no cardiovascular risk factors are considered the picture seems to change. We found evidence of a possible CRP-enhanced functioning of EPCs, by demonstrating that endothelial colony-forming capacity is related to CRP levels in healthy subjects (Ciulla et al., 2006). In order to investigate the burden of angiogenesis in physiological conditions we enrolled 37 subjects who were carefully selected for the lack of cardiovascular risk factors, had low hs-CRP $(<1 \mathrm{mg} / \mathrm{L})$, normal Echocardiogram and carotid Doppler examinations and were not on pharmacological treatment. We found that 15 subjects ( $40.5 \%$ of the sample) formed endothelial cell colonies from peripheral blood and that, relative to the non-colony formers, they had higher levels of hs-CRP as well as of VEGF. These results suggest that CRP may directly increase the clonogenic potential of EPCs, yet it may also be that higher hs-CRP is merely a marker of more active microinflammation - due to minimal endothelial stress- and greater VEGF production. Although the association between hs-CRP and EPC clonogenic capacity appears in contrast with reports from other investigators (Verma et al., 2004), it must be emphasized that we focused on a physiological setting and that the effect of CRP on EPCs may be influenced by different factors such as the concentration and conformation of CRP. For instance, the hsCRP levels in our study were markedly lower $(<0.1 \mathrm{mg} / \mathrm{L})$ than those used for the in vitro demonstration of EPC inhibition (>10 mg/L) (Verma et al., 2004). Indeed Turu and colleagues subsequently showed that CRP at concentrations of $1-5 \mathrm{mg} / \mathrm{L}$ had a strong proangiogenic effect on bovine aortic and human coronary artery endothelial cells and that this was in part mediated by the expression of the VEGF receptor (Turu et al., 2008). Also, it is increasingly acknowledged that CRP exists in two distinct conformations, native circulating CRP and monomeric tissue-associated CRP, and that it is the latter which is responsible for the proangiogenic actions of CRP (Schwedler et al., 2006; Slevin and Krupinski, 2009; Slevin et al., 2010). Whatever the interpretation, the finding of colonyforming potential in healthy individuals underscores the notion that vascular integrity is a "round-the-clock" process characterized by a continuous balance between endothelial injury and regeneration- i.e. between environmental challenges and genetically-determined functional reserve. In this perspective cardiovascular disease can be viewed as the result of a disruption of this balance, with the threshold between physiology and pathology being specific for each single individual.

\section{Current and extra demands on the endothelium, the tip of the iceberg}

The endothelial cells lining the blood vessels are continuously exposed to different kinds of stimuli consisting in changes in the physicochemical characteristics of blood. These reflect the interplay between the internal and external environments, are transmitted by the pulsatile blood flow generated by the pressure gradient produced by the heart, and can trigger inflammation. We have already seen that environmental changes requiring an active response from the cell can be called demands. Demands can be further classified in current or extra according to the efficiency with which they can be handled by the homeostatic machinery. Current demands can be adequately dealt with in a physiological context, even though some degree of cell injury can still occur. Extra demands cannot be 
sufficiently buffered and lead to functional impairment and, eventually, disease. Since the circulation of blood is a highly dynamic phenomenon it can be argued that current demands represent the bulk of all demands while extra demands are more often occasional. If we use the iceberg metaphor, current demands represent the huge part of the iceberg below the water while extra demands causing disease are only the tip of the iceberg. The water line is the boundary between health and overt disease, which varies from individual to individual according to the genetic program. Between overt disease and health we must conceive a grey zone (subclinical disease) in which disease may be unrecognized due to lack of knowledge or appropriate communication (Figure 2).

In the following paragraphs we will discuss the effect on the endothelium of blood pressure (BP) and high altitude (real or simulated) - taken as instances of current demands- as well as of ischemia, exemplifying an extra demand.
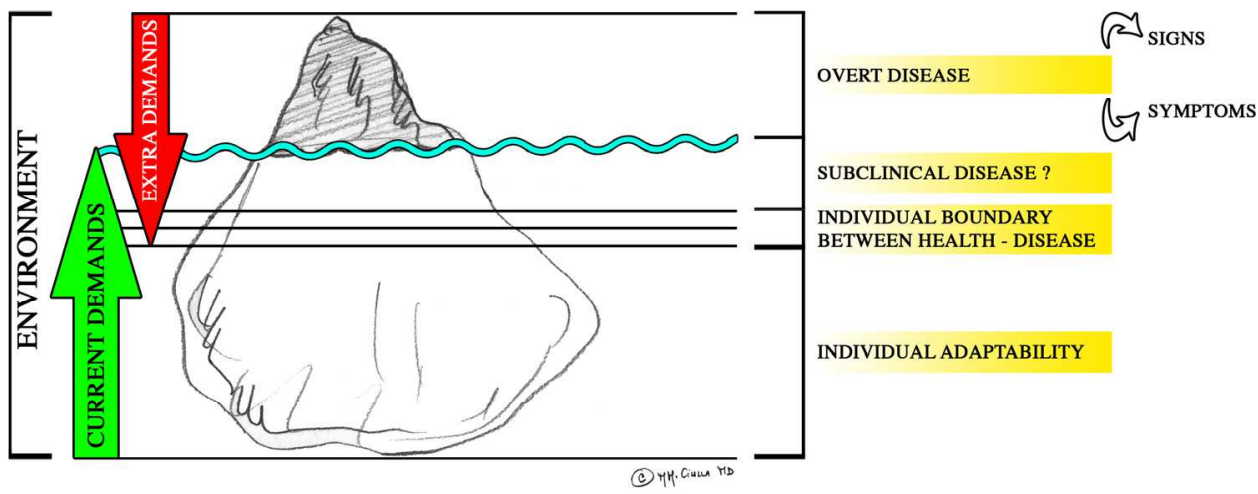

Fig. 2. The iceberg of disease

Pictorial representation of the iceberg metaphor, illustrating the boundary between health (as a result of individual adaptability) and disease. The tip of the iceberg corresponds to overt disease; the huge part below the water line is where individual adaptability successfully buffers environmental demands; just below the surface is the grey zone of subclinical disease. Demands are defined as current or extra according to how efficiently they can be handled by the single organism.

\subsection{Blood pressure as a mechanical stimulus}

$\mathrm{BP}$ is a highly dynamic phenomenon, whose profile is characterized by a series of peaks and nadirs, and it is one of the most important mechanical stimuli acting on vessels. Thus the endothelium is constantly exposed to enormous shear stress (Lu and Kassab, 2011), defined as the component of stress coplanar with a material cross-section and tending to cause a deformation of the material by slippage along this plane. Although it has been shown that exercise can increase circulating EPCs in mice (Cheng et al., 2010; Laufs et al., 2004) and humans (Rehman et al., 2004) and that shear stress promotes endothelial differentiation of EPCs in vitro (Ye et al., 2008) there is scant information on the specific effect of BP on endothelial turnover in healthy subjects. In order to address this issue we enrolled 12 normotensive volunteers who underwent a cycloergometer stress test (Bruce protocol) with BP monitoring (Ciulla et al., 2009). Samples of peripheral blood were obtained immediately 
before and after the test to determine the number of EPCs and circulating endothelial cells (CECs). The latter are mature endothelial cells that are dislodged from the endothelium by injurious stimuli via different mechanisms of cell detachment, including apoptosis and cytokine-mediated proteolysis of the ECM (Dignat-George and Sampol, 2000; Hunting et al., 2005; Mikirova et al., 2009). They can be considered a marker of vascular injury and their levels are generally proportional to those of EPCs (Hunting et al., 2005). We found that the number of CECs increased significantly (1.5-fold) with exercise and that such increase was directly associated with the value of peak systolic BP. The number of EPCs also increased, albeit not in a statistically significant way, probably because their mobilization from the BM requires a longer time. It can therefore be speculated that in physiological conditions BP fluctuations contribute to the renewal of the endothelium by a "mechanical clean-up" process, with systolic BP peaks removing damaged endothelial cells, just like the wind blows away the withered leaves from a tree. On the contrary, in hypertensive subjects, in whom BP levels are constantly elevated with frequent peaks, BP and shear stress can cause damage to the endothelium (Figure 3).

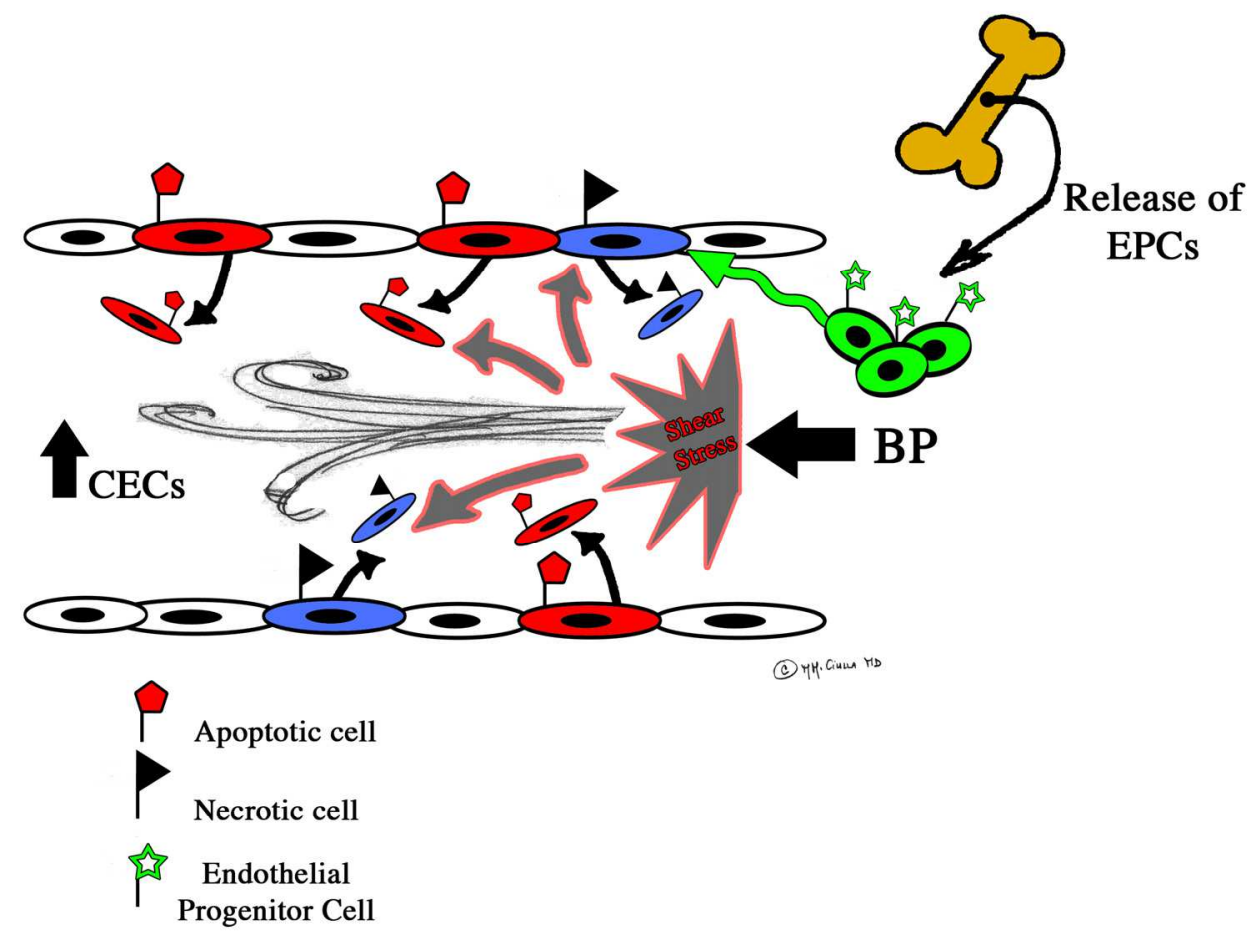

Fig. 3. Effect of blood pressure on the endothelium

Schematic illustration of the effects of shear stress on endothelial turnover. In healthy subjects systolic blood pressure peaks are responsible for a "mechanical clean up" process by dislodging damaged cells, thereby increasing the number of CECs. Concurrently, EPCs are moblized from the bone marrow into the circulation to replace detached cells. In hypertensives, BP may cause direct damage to the endothelium. 


\subsection{Hypoxia: a common cause of cell damage}

Hypoxia is defined as a decrease in the normal level of tissue oxygen tension and can be classified as hypoxic or ischemic based on the underlying pathophysiological mechanism. Hypoxic hypoxia is characterized by a low partial pressure of oxygen in arterial blood $\left(\mathrm{PaO}_{2}\right)$ while in ischemic hypoxia $\mathrm{PaO}_{2}$ is normal, and so is the oxygen content of blood, but oxygen delivery to tissues is impaired because of a reduction in blood flow (Kumar et al., 2011).

It is widely acknowledged that hypoxia and inflammation are closely intertwined: hypoxia stimulates the production of proinflammatory cytokines and inflammation is associated with tissue hypoxia due to the increased metabolic demands of cells (Eltzschig and Carmeliet, 2011; Frede et al., 2007). The link to angiogenesis is established via VEGF which is expressed in response to both hypoxia and proinflammatory cytokines (IL-1, TNF) (Homsi and Daud, 2007; Naldini and Carraro, 2005). At a molecular level, hypoxia and cytokines mainly rely on two distinct signaling pathways in which upregulation of the VEGF gene is brought about by Hypoxia Inducible Factor-1 (HIF-1) (Dehne and Brune, 2009; Eltzschig and Carmeliet, 2011; Harris, 2002; Jewell et al., 2001) and Nuclear Factor kappa-B (NFkB) respectively (Hofer and Schweighofer, 2007; Huang et al., 2000; Sprague and Khalil, 2009; Winsauer and de Martin, 2007). HIF is a heterodimeric transcription factor composed of a

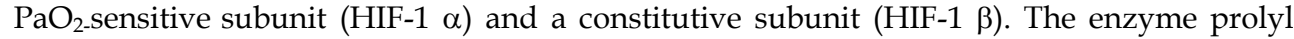
hydroxylase (PHD) acts as an oxygen sensor within the cell since in normoxic conditions it is activated and hydroxylates proline residues on the HIF-1 $\alpha$ subunit, thus creating a binding site for the Von Hippel Lindau protein (VHL). The interaction with VHL then causes HIF-1 $\alpha$ to become ubiquitylated and targeted to the proteosome for degradation. Conversely, in hypoxic conditions PHD is inactive, HIF-1 is stabilized and translocates to the nucleus where it binds to hypoxia-responsive elements (HRE) in oxygen-responsive genes such as VEGF. NFkB is a heterodimeric transcription factor consisting of the p50 and p65 subunits. Normally it is associated to an inhibitory protein ( $\mathrm{IKBa}$ ) which retains it in the cytoplasm. Upon stimulation by IL-1 and TNF, IKBa is phosphorylated on two serine residues by a specific kinase (IKK) and undergoes ubiquitylation and proteosomal degradation. This allows translocation of NFkB to the nucleus where it binds to the promoter regions of genes encoding a number of biologically active molecules such as VEGF and proinflammatory cytokines. It must however be emphasized that the hypoxia and cytokine signaling pathways intersect at multiple points, consistently with the notion of an extensive cross-talk between hypoxia and inflammation. For instance, IL-1 and TNF are both able to activate HIF-1 (Dehne and Brune, 2009; Frede et al., 2007); HIF can stimulate the transcription of NFkB and NFkB can do the same with HIF (Angelo and Kurzrock, 2007; Eltzschig and Carmeliet, 2011); hypoxia leads to the formation of hydrogen peroxide which directly activates NFkB (Angelo and Kurzrock, 2007).

Although VEGF is the key player in angiogenesis, other proangiogenic factors deserve a brief mention, namely Hepatocte Growth Factor (HGF), Erythropoietin (Epo) and Stromal Cell Derived Factor-1 (SDF-1). HFG, also known as Scatter Factor (SF), is a large multidomain protein similar to plasminogen which is produced by cells of mesenchymal origin (such as vascular smooth muscle cells, pericytes and fibroblasts) and acts in a paracrine way on neighbouring endothelial cells via its receptor, a transmembrane tyrosine kinase encoded by the Met proto-oncogene (Abounader and Laterra, 2005; Desiderio, 2007; Ding et al., 2003; Schroder et al., 2010). It has been shown to be a powerful stimulator of angiogenesis, mobilizing EPCs from the BM into the circulation, either directly or by 
promoting the expression of VEGF (Desiderio, 2007; Schroder et al., 2010; Zhang et al., 2005; Zhu et al., 2010). Epo, better known for its effects on the hematopoietic system, has also gained recognition as an enhancer of endothelial cell functions, especially for its ability to mobilize EPCs from the BM (Bahlmann et al., 2004; Heeschen et al., 2003; Schroder et al., 2010). The chemokine SDF-1/CXCL12 and its receptor CXCR4 have been found to regulate the mobilization of EPCs from the BM and their homing to sites of tissue injury (Shen et al., 2011; Walter et al., 2005). Remarkably, also HGF, Epo and SDF-1 are involved in the HIF-1 signaling pathway: the former can induce HIF-1 $\alpha$ (Desiderio, 2007), the latter (and CRXR4) are activated by HIF-1 (Dehne and Brune, 2009; Harris, 2002).

Several studies have investigated the effect of hypoxic hypoxia on EPCs, both in vitro and in vivo. In vitro, it has been shown that rat EPCs exposed for 48 hours to $5 \% \mathrm{O}_{2}$ improved their ability to proliferate, migrate and express VEGF (Wang et al., 2010). Similarly, human peripheral blood mononuclear cells (PB-MC) cultured for one week in hypoxic conditions were stimulated to differentiate into EPCs and express VEGF (Akita et al., 2003), and human EPCs cultured in $1 \% \mathrm{O}_{2}$ were found to accumulate HIF-1 and upregulate VEGF (Abaci et al., 2010). In vivo, hypoxic hypoxia can be obtained either by exposure to a low fraction of inspired oxygen $\left(\mathrm{FiO}_{2}\right)$ - i.e. normobaric hypoxia- or to a low atmospheric pressure - i.e. hypobaric hypoxia. In a mouse model of normobaric hypoxia a significant increase in circulating EPCs was observed after exposure to a $10 \% \mathrm{FiO}_{2}$ for four days (Schroder et al., 2009). In healthy subjects we demonstrated that breathing through a hypoxicator an oxygen mixture at $11.2 \%$ (corresponding to a simulated altitude of $4850 \mathrm{~m}$ above sea level) for one hour resulted in a marked increase in the number of PB-EPCs, which then normalized after one week, and that the percentage increase in EPCs from baseline was inversely correlated with the baseline $\mathrm{PaO}_{2}$ (Ciulla et al., 2007a). In keeping with the underlying molecular mechanisms, we also found that such brief standardized hypoxia was associated with an increase in the serum levels of HGF and Epo as well in the expression of HIF-1 within EPCs (Ciulla et al., 2007a). In a healthy individual undergoing a trek in the Himalayas at a mean altitude of $3900 \mathrm{~m}$ we described a significant increase in the number and clonogenic activity of EPCs one day after the trek, returning to normal after 45 days at sea level (Ciulla et al., 2005). A recent study conducted on healthy volunteers participating in a one-week hiking program on the Austrian Alps at $1700 \mathrm{~m}$ reported an increase in circulating EPCs (Schobersberger et al., 2010). It must however be remarked that in the case of these high- and moderate-altitude studies it is not possible to dissociate the effects of hypoxia from those of physical activity which is also a powerful stimulus for EPC upregulation (Cheng et al., 2010; Laufs et al., 2004).

With regard to ischemic hypoxia there is a wealth of evidence from animal and human studies that acute ischemic conditions are marked by an increase in plasma levels of VEGF and in the number of EPCs in the PB. In rabbit and murine models of hindlimb ischemia (Takahashi et al., 1999) an increase in the frequency of circulating EPCs, reaching a maximum 1 week after the onset of ischemia, has been described. In a murine model of soft tissue ischemia (Tepper et al., 2005) VEGF levels were found to be increased by 2.5-fold after one week and correlated with the levels of circulating EPCs. As far as human studies are concerned, researchers have mainly investigated vascular diseases such as myocardial infarction (MI), ischemic stroke (IS) and peripheral artery disease (PAD). In the first study carried out on patients with acute MI (Shintani et al., 2001), the levels of VEGF and EPCs in the peripheral blood were significantly increased relative to controls the first day after the event and peaked at one week. Moreover, they were closely correlated, supporting the notion that VEGF induces EPC mobilization from the BM. Subsequent studies demonstrated 
an increase in the number of EPCs, peaking on admission, in patients with recent STelevation MI (<12 hours) (Wojakowski et al., 2004), and elevated levels of EPCs in patients with acute MI as early as 3 hours from the onset of symptoms (Massa et al., 2009). Over the last years several studies on patients with acute IS stroke have also been conducted, showing that EPCs are mobilized in response to cerebral ischemia and that the extent of such mobilization appears to have a prognostic value in terms of the likelihood of recovery. In patients with acute IS a two-fold mean increase in peripheral blood mononuclear CD34+ cells has been found when compared to healthy controls and it has been demonstrated that neurological and functional outcomes at one and three months were significantly improved in those defined as "high mobilizers" (count > 15000 cells/ml) (Dunac et al., 2007). In a similar study (Sobrino et al., 2007), patients with a greater EPC rise during the first week after a first-ever nonlacunar IS had better outcomes at three months according to the National Institutes of Health Stroke Scale (NIHSS) and the Rankin Scale (RS). In a larger sample of patients with IS (Yip et al., 2008), circulating levels of EPCs were about twice higher in subjects with IS than in controls matched for risk factors, and low ECP levels were predictive of both severe concurrent neurological impairment at the NIHSS and combined major adverse outcomes at three months. Finally, Sandri and colleagues (Sandri et al., 2005; Sandri et al., 2011) investigated the acute and chronic effects of exercise-induced peripheral limb ischemia in subjects with PAD. After four weeks of ischemic treadmill training PAD patients exhibited a 3-fold increase in VEGF levels and a four-fold increase in EPCs (Sandri et al., 2005). After a single maximal treadmill test, VEGF levels increased more than fourfold after one day and EPCs rose three-fold at one to two days (Sandri et al., 2011).

\section{Enumerating ECPs: a tricky question}

CD34+VEGFR-2+CD133+ cells are more similar to hematopoietic-derived cells, which may contribute to vascular repair and homeostasis in an indirect manner. In fact cells belonging to the hematopoietic lineage can be recruited to injured or angiogenic sites and secrete regulatory cytokines that promote vessel homeostasis and repair by local cells, including local vessel wall ECs. It is possible that cardiovascular risk factors and established cardiovascular disease decrease the circulating number and properties of the hematopoieticderived cells. Hence, low levels of these circulating cells might correlate with adverse cardiovascular outcomes. However, this concept is entirely different from the notion of EPC which was proposed 10 years ago, when EPCs were suggested to function as a structural backup from the BM (Asahara et al., 1997). Mature hematopoietic cells include red blood cells, platelets, myeloid cells such as monocytes/macrophages and granulocytes, dendritic cells and lymphoid cells including B cells, T cells, NK cells and NKT cells. Hematopoietic cells derive from HSCs and hematopoietic progenitor cells (HPCs) that reside within the BM. Importantly, hematopoietic-derived cells such as monocytes, granulocytes, platelets and even HSCs/HPCs have been shown to be involved in vascular repair (Heil et al., 2006; Langer et al., 2006). However, because both endothelial lineage cells and hematopoietic cells are present at sites of neovascularization and co-express a host of similar surface markers, it can be difficult to discriminate them from each other at sites of vascular repair, and appreciate their individual contribution to the healing or regenerative process. Therefore, the diverse cell types now known to be recruited at sites of neo- vascularization are highly likely to have previously been lumped into the single term 'EPC' in many early studies of postnatal vasculogenesis, explaining some of the apparent controversy in the field. 
One of the models that has been used to directly investigate donor cell differentiation into ECs in vivo has been a transgenic mouse whose cells express a fluorescent marker (e.g. green fluorescent protein (GFP)) only in the presence of an endothelium-specific gene, such as Tie-2 (Schlaeger et al., 1997). Therefore, transplantation of BM cells from transgenic mice into wild-type mice allows the tracking of the cells of interest, and of their fate during mobilization from the BM into sites of vascular injury, and discriminates them from other cell types and from the host cells involved in vascular repair and regeneration. However, even these sophisticated approaches have often yielded contradictory results, probably because the expression of Tie-2 is not entirely restricted to the endothelial lineage, but is also found in pericytes and hematopoietic (derived) cells such as monocytes, that also migrate to sites of vascular repair (De Palma et al., 2003).

On the other hand, it has been argued that the failure to retrieve genetically labelled BMderived Tie-2+ ECs in the work by De Palma et al. might be due to the fact that the exogenous Tie-2 promoter used may not mark all mature ECs, or that during the random genetic manipulation of cells the CEPC population might not have been targeted with the viral Tie-2 vector (Nolan et al., 2007). Also, it is possible that the failure to detect few, if any, BM-derived ECs in the neovasculature of experimental models may be related to poor engraftment of the EPC compartment following its transplantation (De Palma et al., 2003; Gothert et al., 2005). Although the latter pitfall can be circumvented by the use of a parabiosis model (where two mice are surgically connected and share a common circulatory system allowing exchange of circulating cells), conflicting results have also been reported in the parabiosis model (Purhonen et al., 2008).

In order to definitely demonstrate in vivo that the EPC-derived progeny in the newly formed vasculature is truly endothelial in nature, a more direct or convincing approach would be to extract the putative EPC progeny from tissues (by means of a genetic tracer such as GFP) and FACS-analyze these cells (with or without previous culturing) using a wide panel of antigens (CD11, CD45, VE-Cadherin, CD146, CD31, CD13, CD105, etc.) so as to be able to discriminate them from other cell lineages, especially the hematopoietic one. In addition, these extracted cells could also be tested functionally by evaluating their proliferative or tube-forming capacity. So far, only one group has used such a FACS-based strategy to identify EPC progeny in vivo (Nolan et al., 2007), but the combination of markers used (CD31+Lectin+GFP+) does not allow a clear discrimination from hematopoietic (derived) cells that also display the same functional abilities (Nolan et al., 2007; Yoder et al., 2007).

Other methodological issues - such as the number of tissue sites sampled, the time frame of the study intervals, and the microscopic technique employed in tissue analysis - may explain why in different animal models different findings were obtained with regard to the extent of EPC contribution to neovascularization. For instance, while the use of confocal microscopy may permit a complete volumetric 3-dimensional rendering of donor cell contribution to new blood vessels in a damaged tissue, the use of light microscopy can make it difficult to discriminate whether cells are are integrated within the endothelial layer, or merely located at periluminal sites, just beneath the endothelial layer (De Palma et al., 2003; Galimi et al., 2005). Thus, differences in the microscopic technique, and/or in the method of image analysis, may also account for the huge variability in the rate of EPC incorporation into repairing vessels that has been reported in the literature, ranging from 0 to $90 \%$. Furthermore, it remains uncertain how many of the 'luminal integrated cells' (e.g. monocytes, that phenotypically overlap with ECs) are in fact passenger cells participating in 
an inflammatory reaction to vascular injury, or cells in the process of transmigrating deeper into the vessel wall and interstitial tissues. Thus, whenever possible, the use of 3dimensional imaging, coupled with antibodies which are specific and validated for the identification of cells and subcellular organelles as well as extracellular structures, provides the most sensitive and specific information on the location and contribution of donor cells to tissues under repair.

As it is increasingly recognized that cell fate changes are a property of stem cells (Blau et al., 2001) there arises the need to adopt more stringent criteria to determine if a cell fate transition has taken place. Blau and colleagues (Blau et al., 2001) propose a set of such criteria. The first criterion is the demonstration that the cell expresses a previously silent gene specific for the new cell type. This can be accomplished by investigating protein expression via antibodies and FACS analysis. Of course, in vivo evaluation must be considered superior to in vitro evaluation. The second criterion is the demonstration that the cell is well integrated into the tissue and has acquired morphological characteristics identical to those of neighbouring resident cells. The third -and most important- criterion is the demonstration, by means of a functional assay, that the cell is able to perform tissuespecific functions. For instance, using appropriate genetically-modified animal models it can be shown that it produces de novo an organ-specific molecule which is essential for survival or improvement of disease-associated deficits. With reference to the cardiovascular domain, convincing evidence of a cell fate transition in BM-derived cells could be obtained by verifying that these cells not only produce myocardium-specific proteins but are also able to contract in synchrony with the cardiac syncytia.

\section{Conclusion}

The circulatory system is involved in the transport of a wide variety of biological molecules and cells and can be considered the body's basic communication system. It consists of an intricate network of vessels lined by endothelium. Although the endothelium has long been viewed as an inert layer of "nucleated cellophane" its highly dynamic nature is being increasingly recognized. Endothelial cells are exposed round the clock to proinflammatory stimuli of different kinds (mechanical, chemical, biological), even in healthy individuals, and vascular homeostasis is ensured by a continuous balance between injury and repairi.e. between environmental challenges and genetically-determined functional reserve. A disruption of this balance leads to endothelial dysfunction and atherosclerotic disease, with the threshold between physiology (current demands) and pathology (extra demands) being different and specific for each individual, as unique as is the genome.

There is growing evidence that EPCs are a major player in the process of vessel regeneration, being mobilized from the $B M$ into the $P B$ and homing to sites of injury where they are incorporated into the neoendothelium to serve a structural and paracrine role. Indeed we demonstrated, in an animal model of myocardial cryodamage, that peripherally injected BM mononuclear cells are able to target the site of damage and form early-stage small vessels.

Since 1997, when Asahara and colleagues isolated EPCs from human PB by means of magnetic beads, the identity and characterization of EPCs have been the subject of heated debate. However, it is generally accepted that progenitor cells similar to embryonic hemangioblasts participate in adult angiogenesis, thus establishing the notion of postnatal vasculogenesis. 
In complex organisms inflammation and angiogenesis are closely related and the endothelial cell lies at the very core of this association. Inflammatory cells secrete cytokines (IL-1 and TNF) which elicit VEGF production from the endothelium. VEGF, in turn, is a powerful proangiogenic factor which regulates EPC kinetics and stimulates inflammatory cells. Such extensive communication between endothelial and inflammatory cells is the basis of the inflammation-angiogenesis cross-talk.

There is a wealth of evidence from animal and human studies that ischemia enhances the number and functions of circulating EPCs. Less information is available on the effect of physiological stimuli on EPCs or CECs in healthy subjects. Our group showed that blood pressure-induced shear stress increases the number of CECs, that hypoxia (normo- and hypobaric) increases the number and/or clonogenic capacity of EPCs, and that hs-CRP levels are higher in colony-formers.

\section{References}

Abaci, HE, Truitt, R, Luong, E, Drazer, G, Gerecht, S (2010) Adaptation to oxygen deprivation in cultures of human pluripotent stem cells, endothelial progenitor cells, and umbilical vein endothelial cells. In: Am J Physiol Cell Physiol: United States, pp. C1527-1537.

Abounader, R, Laterra, J (2005) Scatter factor/hepatocyte growth factor in brain tumor growth and angiogenesis. Neuro Oncol 7: 436-451.

Akita, T, Murohara, T, Ikeda, H, Sasaki, K, Shimada, T, Egami, K, Imaizumi, T (2003) Hypoxic preconditioning augments efficacy of human endothelial progenitor cells for therapeutic neovascularization. Lab Invest 83: 65-73.

Anagnostou, A, Liu, Z, Steiner, M, Chin, K, Lee, ES, Kessimian, N, Noguchi, CT (1994) Erythropoietin receptor mRNA expression in human endothelial cells. Proc Natl Acad Sci U S A 91: 3974-3978.

Angelo, LS, Kurzrock, R (2007) Vascular endothelial growth factor and its relationship to inflammatory mediators. In: Clin Cancer Res: United States, pp. 2825-2830.

Asahara, T, Masuda, H, Takahashi, T, Kalka, C, Pastore, C, Silver, M, Kearne, M, Magner, M, Isner, JM (1999) Bone marrow origin of endothelial progenitor cells responsible for postnatal vasculogenesis in physiological and pathological neovascularization. Circ Res 85: 221-228.

Asahara, T, Murohara, T, Sullivan, A, Silver, M, van der Zee, R, Li, T, Witzenbichler, B, Schatteman, G, Isner, JM (1997) Isolation of putative progenitor endothelial cells for angiogenesis. Science 275: 964-967.

Asosingh, K, Erzurum, SC, Yoder, MC, Tuder, RM (2009) Letter by asosingh et Al regarding article, "circulating endothelial progenitor cells in patients with eisenmenger syndrome and idiopathic pulmonary arterial hypertension". In: Circulation: United States, p. e230; author reply e231.

Bahlmann, FH, De Groot, K, Spandau, JM, Landry, AL, Hertel, B, Duckert, T, Boehm, SM, Menne, J, Haller, H, Fliser, D (2004) Erythropoietin regulates endothelial progenitor cells. In: Blood: United States, pp. 921-926. 
Bertolini, F, Shaked, Y, Mancuso, P, Kerbel, RS (2006) The multifaceted circulating endothelial cell in cancer: towards marker and target identification. In: Nat Rev Cancer: England, pp. 835-845.

Bittner, RE, Schofer, C, Weipoltshammer, K, Ivanova, S, Streubel, B, Hauser, E, Freilinger, M, Hoger, H, Elbe-Burger, A, Wachtler, F (1999) Recruitment of bone-marrow-derived cells by skeletal and cardiac muscle in adult dystrophic mdx mice. Anat Embryol (Berl) 199: 391-396.

Blau, HM, Brazelton, TR, Weimann, JM (2001) The evolving concept of a stem cell: entity or function? In: Cell: United States, pp. 829-841.

Bompais, H, Chagraoui, J, Canron, X, Crisan, M, Liu, XH, Anjo, A, Tolla-Le Port, C, Leboeuf, M, Charbord, P, Bikfalvi, A, Uzan, G (2004) Human endothelial cells derived from circulating progenitors display specific functional properties compared with mature vessel wall endothelial cells. In: Blood: United States, pp. 2577-2584.

Brazelton, TR, Rossi, FM, Keshet, GI, Blau, HM (2000) From marrow to brain: expression of neuronal phenotypes in adult mice. In: Science: United States, pp. 1775-1779.

Bull, TM, Golpon, H, Hebbel, RP, Solovey, A, Cool, CD, Tuder, RM, Geraci, MW, Voelkel, NF (2003) Circulating endothelial cells in pulmonary hypertension. In: Thromb Haemost: Germany, pp. 698-703.

Butcher, EC (1991) Leukocyte-endothelial cell recognition: three (or more) steps to specificity and diversity. In: Cell: United States, pp. 1033-1036.

Calabro, P, Golia, E, Yeh, ET (2009) CRP and the risk of atherosclerotic events. Semin Immunopathol 31: 79-94.

Calabro, P, Willerson, JT, Yeh, ET (2003) Inflammatory cytokines stimulated C-reactive protein production by human coronary artery smooth muscle cells. In: Circulation: United States, pp. 1930-1932.

Campbell, KH, McWhir, J, Ritchie, WA, Wilmut, I (1996) Sheep cloned by nuclear transfer from a cultured cell line. Nature 380: 64-66.

Cannon, W (1926) Physiological regulation of normal states: some tentative postulates concerning biological homeostatics. Éditions Médicales.

Caplan, BA, Schwartz, CJ (1973) Increased endothelial cell turnover in areas of in vivo Evans Blue uptake in the pig aorta. Atherosclerosis 17: 401-417.

Carmeliet, P (2000) Mechanisms of angiogenesis and arteriogenesis. Nat Med 6: 389-395.

Case, J, Mead, LE, Bessler, WK, Prater, D, White, HA, Saadatzadeh, MR, Bhavsar, JR, Yoder, MC, Haneline, LS, Ingram, DA (2007) Human CD34+AC133+VEGFR-2+ cells are not endothelial progenitor cells but distinct, primitive hematopoietic progenitors. In: Exp Hematol: Netherlands, pp. 1109-1118.

Chen, X, Andresen, BT, Hill, M, Zhang, J, Booth, F, Zhang, C (2008) Role of Reactive Oxygen Species in Tumor Necrosis Factor-alpha Induced Endothelial Dysfunction. Curr Hypertens Rev 4: 245-255.

Cheng, XW, Kuzuya, M, Kim, W, Song, H, Hu, L, Inoue, A, Nakamura, K, Di, Q, Sasaki, T, Tsuzuki, M, Shi, GP, Okumura, K, Murohara, T (2010) Exercise training stimulates ischemia-induced neovascularization via phosphatidylinositol 3-kinase/Aktdependent hypoxia-induced factor-1 alpha reactivation in mice of advanced age. In: Circulation: United States, pp. 707-716. 
Choi, K, Kennedy, M, Kazarov, A, Papadimitriou, JC, Keller, G (1998) A common precursor for hematopoietic and endothelial cells. Development 125: 725-732.

Cines, DB, Pollak, ES, Buck, CA, Loscalzo, J, Zimmerman, GA, McEver, RP, Pober, JS, Wick, TM, Konkle, BA, Schwartz, BS, Barnathan, ES, McCrae, KR, Hug, BA, Schmidt, AM, Stern, DM (1998) Endothelial cells in physiology and in the pathophysiology of vascular disorders. Blood 91: 3527-3561.

Ciulla, MM, Cortiana, M, Silvestris, I, Matteucci, E, Ridolfi, E, Giofre, F, Zanardelli, M, Paliotti, R, Cortelezzi, A, Pierini, A, Magrini, F, Desiderio, MA (2007a) Effects of simulated altitude (normobaric hypoxia) on cardiorespiratory parameters and circulating endothelial precursors in healthy subjects. In: Respir Res: England, p. 58.

Ciulla, MM, Ferrero, S, Gianelli, U, Paliotti, R, Magrini, F, Braidotti, P (2007b) Direct visualization of neo-vessel formation following peripheral injection of bone marrow derived CD34+ cells in experimental myocardial damage. In: Micron: England, pp. 321-322.

Ciulla, MM, Ferrero, S, Lazzari, L, Pacchiana, R, Paliotti, R, Gianelli, U, Busca, G, Esposito, A, Bosari, S, Magrini, F, Rebulla, P (2004) The translocation of marrow MNCs after experimental myocardial cryoinjury is proportional to the infarcted area. In: Transfusion: United States, pp. 239-244.

Ciulla, MM, Gianni, C, Broglia, P, Lonati, S, Silvestris, I, Paliotti, R, Giofre, F, Rampoldi, E, Cortelezzi, A, Magrini, F (2009) Systolic blood pressure peak during maximal exercise testing: a possible determinant of endothelial turnover in healthy subjects. Am J Hematol 84: 449-450.

Ciulla, MM, Giorgetti, A, Giordano, R, Silvestris, I, Cortiana, M, Paliotti, R, Lazzari, L (2007c) Circulating endothelial progenitor cell colony-forming capacity in healthy subjects: how does an endothelial colony look like? In: Am J Cardiol: United States, pp. 559-560.

Ciulla, MM, Giorgetti, A, Lazzari, L, Cortiana, M, Silvestris, I, Annoni, G, De Asmundis, C, Fiore, AV, Montelatici, E, Paliotti, R, Magrini, F, Rebulla, P, Cortelezzi, A (2005) High-altitude trekking in the Himalayas increases the activity of circulating endothelial cells. Am J Hematol 79: 76-78.

Ciulla, MM, Giorgetti, A, Silvestris, I, Cortiana, M, Montelatici, E, Paliotti, R, Annoni, GA, Fiore, AV, Giordano, R, De Marco, F, Magrini, F, Rebulla, P, Cortelezzi, A, Lazzari, L (2006) Endothelial colony forming capacity is related to C-reactive protein levels in healthy subjects. Curr Neurovasc Res 3: 99-106.

Ciulla, MM, Lazzari, L, Pacchiana, R, Esposito, A, Bosari, S, Ferrero, S, Gianelli, U, Paliotti, R, Busca, G, Giorgetti, A, Magrini, F, Rebulla, P (2003) Homing of peripherally injected bone marrow cells in rat after experimental myocardial injury. Haematologica 88: 614-621.

De Palma, M, Venneri, MA, Roca, C, Naldini, L (2003) Targeting exogenous genes to tumor angiogenesis by transplantation of genetically modified hematopoietic stem cells. In: Nat Med: United States, pp. 789-795.

Dehne, N, Brune, B (2009) HIF-1 in the inflammatory microenvironment. In: Exp Cell Res: United States, pp. 1791-1797. 
Del Papa, N, Colombo, G, Fracchiolla, N, Moronetti, LM, Ingegnoli, F, Maglione, W, Comina, DP, Vitali, C, Fantini, F, Cortelezzi, A (2004) Circulating endothelial cells as a marker of ongoing vascular disease in systemic sclerosis. Arthritis Rheum 50: 1296-1304.

Delorme, B, Basire, A, Gentile, C, Sabatier, F, Monsonis, F, Desouches, C, Blot-Chabaud, M, Uzan, G, Sampol, J, Dignat-George, F (2005) Presence of endothelial progenitor cells, distinct from mature endothelial cells, within human CD146+ blood cells. In: Thromb Haemost: Germany, pp. 1270-1279.

Desiderio, MA (2007) Hepatocyte growth factor in invasive growth of carcinomas. Cell Mol Life Sci 64: 1341-1354.

DeWitt, N (2005) Angiogenesis. Nature, p. 931.

Dignat-George, F, Sampol, J (2000) Circulating endothelial cells in vascular disorders: new insights into an old concept. Eur J Haematol 65: 215-220.

Diller, GP, van Eijl, S, Okonko, DO, Howard, LS, Ali, O, Thum, T, Wort, SJ, Bedard, E, Gibbs, JS, Bauersachs, J, Hobbs, AJ, Wilkins, MR, Gatzoulis, MA, Wharton, J (2008) Circulating endothelial progenitor cells in patients with Eisenmenger syndrome and idiopathic pulmonary arterial hypertension. In: Circulation: United States, pp. 3020-3030.

Ding, S, Merkulova-Rainon, T, Han, ZC, Tobelem, G (2003) HGF receptor up-regulation contributes to the angiogenic phenotype of human endothelial cells and promotes angiogenesis in vitro. In: Blood: United States, pp. 4816-4822.

Dunac, A, Frelin, C, Popolo-Blondeau, M, Chatel, M, Mahagne, MH, Philip, PJ (2007) Neurological and functional recovery in human stroke are associated with peripheral blood CD34+ cell mobilization. J Neurol 254: 327-332.

Ebrahem, Q, Chaurasia, SS, Vasanji, A, Qi, JH, Klenotic, PA, Cutler, A, Asosingh, K, Erzurum, S, Anand-Apte, B (2010) Cross-talk between vascular endothelial growth factor and matrix metalloproteinases in the induction of neovascularization in vivo. In: Am J Pathol: United States, pp. 496-503.

Eltzschig, HK, Carmeliet, P (2011) Hypoxia and inflammation. N Engl J Med 364: 656-665.

Fadini, GP, Baesso, I, Albiero, M, Sartore, S, Agostini, C, Avogaro, A (2008) Technical notes on endothelial progenitor cells: ways to escape from the knowledge plateau. In: Atherosclerosis: Ireland, pp. 496-503.

Fina, L, Molgaard, HV, Robertson, D, Bradley, NJ, Monaghan, P, Delia, D, Sutherland, DR, Baker, MA, Greaves, MF (1990) Expression of the CD34 gene in vascular endothelial cells. Blood 75: 2417-2426.

Flamme, I, Risau, W (1992) Induction of vasculogenesis and hematopoiesis in vitro. Development 116: 435-439.

Frede, S, Berchner-Pfannschmidt, U, Fandrey, J (2007) Regulation of hypoxia-inducible factors during inflammation. In: Methods Enzymol: United States, pp. 405-419.

Friedrich, EB, Walenta, K, Scharlau, J, Nickenig, G, Werner, N (2006) CD34/CD133+/VEGFR-2+ endothelial progenitor cell subpopulation with potent vasoregenerative capacities. In: Circ Res: United States, pp. e20-25.

Furusawa, C, Kaneko, K (2000) Complex organization in multicellularity as a necessity in evolution. Artif Life 6: 265-281. 
Galimi, F, Summers, RG, van Praag, H, Verma, IM, Gage, FH (2005) A role for bone marrowderived cells in the vasculature of noninjured CNS. In: Blood: United States, pp. 2400-2402.

Galley, HF, Webster, NR (2004) Physiology of the endothelium. In: Br J Anaesth: England, pp. 105-113.

Geard, N, Wiles, J (2005) A gene network model for developing cell lineages. Artif Life 11: 249-267.

Genest, J (2010) C-reactive protein: risk factor, biomarker and/or therapeutic target? Can J Cardiol 26 Suppl A: 41A-44A.

George, AL, Bangalore-Prakash, P, Rajoria, S, Suriano, R, Shanmugam, A, Mittelman, A, Tiwari, RK (2011) Endothelial progenitor cell biology in disease and tissue regeneration. In: J Hematol Oncol: England, p. 24.

George, F, Brouqui, P, Boffa, MC, Mutin, M, Drancourt, M, Brisson, C, Raoult, D, Sampol, J (1993) Demonstration of Rickettsia conorii-induced endothelial injury in vivo by measuring circulating endothelial cells, thrombomodulin, and von Willebrand factor in patients with Mediterranean spotted fever. Blood 82: 2109-2116.

Goon, PK, Boos, CJ, Stonelake, PS, Blann, AD, Lip, GY (2006) Detection and quantification of mature circulating endothelial cells using flow cytometry and immunomagnetic beads: a methodological comparison. In: Thromb Haemost: Germany, pp. 45-52.

Gothert, JR, Gustin, SE, Hall, MA, Green, AR, Gottgens, B, Izon, DJ, Begley, CG (2005) In vivo fate-tracing studies using the $\mathrm{Scl}$ stem cell enhancer: embryonic hematopoietic stem cells significantly contribute to adult hematopoiesis. In: Blood: United States, pp. 2724-2732.

Gurdon, JB (1960) The developmental capacity of nuclei taken from differentiating endoderm cells of Xenopus laevis. J Embryol Exp Morphol 8: 505-526.

Gussoni, E, Soneoka, Y, Strickland, CD, Buzney, EA, Khan, MK, Flint, AF, Kunkel, LM, Mulligan, RC (1999) Dystrophin expression in the mdx mouse restored by stem cell transplantation. Nature 401: 390-394.

Harris, AL (2002) Hypoxia--a key regulatory factor in tumour growth. Nat Rev Cancer 2: 3847.

Haudenschild, C, Studer, A (1971) Early interactions between blood cells and severely damaged rabbit aorta. Eur J Clin Invest 2: 1-7.

Haudenschild, CC, Schwartz, SM (1979) Endothelial regeneration. II. Restitution of endothelial continuity. Lab Invest 41: 407-418.

Hay, ED (1991) Collagen and other matrix glycoproteins in embryogenesis. In: Cell biology of extracellular matrix. Press, NYP, Ed., pp. 419-462.

Heeschen, C, Aicher, A, Lehmann, R, Fichtlscherer, S, Vasa, M, Urbich, C, Mildner-Rihm, C, Martin, H, Zeiher, AM, Dimmeler, S (2003) Erythropoietin is a potent physiologic stimulus for endothelial progenitor cell mobilization. In: Blood: United States, pp. 1340-1346.

Heil, M, Eitenmuller, I, Schmitz-Rixen, T, Schaper, W (2006) Arteriogenesis versus angiogenesis: similarities and differences. In: J Cell Mol Med: Romania, pp. 45-55. 
Hofer, E, Schweighofer, B (2007) Signal transduction induced in endothelial cells by growth factor receptors involved in angiogenesis. In: Thromb Haemost: Germany, pp. 355363.

Homsi, J, Daud, AI (2007) Spectrum of activity and mechanism of action of VEGF/PDGF inhibitors. Cancer Control 14: 285-294.

Hong, YJ, Jeong, MH, Lim, SY, Lee, SR, Kim, KH, Sohn, IS, Park, HW, Kim, JH, Kim, W, Ahn, Y, Cho, JG, Park, JC, Kang, JC (2005) Elevated preprocedural high-sensitivity C-reactive protein levels are associated with neointimal hyperplasia and restenosis development after successful coronary artery stenting. In: Circ J: Japan, pp. 14771483.

Hristov, M, Erl, W, Weber, PC (2003a) Endothelial progenitor cells: isolation and characterization. In: Trends Cardiovasc Med: United States, pp. 201-206.

Hristov, M, Erl, W, Weber, PC (2003b) Endothelial progenitor cells: mobilization, differentiation, and homing. In: Arterioscler Thromb Vasc Biol: United States, pp. 1185-1189.

Huang, S, Robinson, JB, Deguzman, A, Bucana, CD, Fidler, IJ (2000) Blockade of nuclear factor-kappaB signaling inhibits angiogenesis and tumorigenicity of human ovarian cancer cells by suppressing expression of vascular endothelial growth factor and interleukin 8. Cancer Res 60: 5334-5339.

Hung, MJ, Cherng, WJ, Yang, NI, Cheng, CW, Li, LF (2005) Relation of high-sensitivity Creactive protein level with coronary vasospastic angina pectoris in patients without hemodynamically significant coronary artery disease. In: Am J Cardiol: United States, pp. 1484-1490.

Hunting, CB, Noort, WA, Zwaginga, JJ (2005) Circulating endothelial (progenitor) cells reflect the state of the endothelium: vascular injury, repair and neovascularization. In: Vox Sang: England, pp. 1-9.

Ii, M, Takenaka, H, Asai, J, Ibusuki, K, Mizukami, Y, Maruyama, K, Yoon, YS, Wecker, A, Luedemann, C, Eaton, E, Silver, M, Thorne, T, Losordo, DW (2006) Endothelial progenitor thrombospondin-1 mediates diabetes-induced delay in reendothelialization following arterial injury. In: Circ Res: United States, pp. 697704 .

Ingram, DA, Mead, LE, Moore, DB, Woodard, W, Fenoglio, A, Yoder, MC (2005) Vessel wall-derived endothelial cells rapidly proliferate because they contain a complete hierarchy of endothelial progenitor cells. In: Blood: United States, pp. 2783-2786.

Inoue, T, Kato, T, Uchida, T, Sakuma, M, Nakajima, A, Shibazaki, M, Imoto, Y, Saito, M, Hashimoto, S, Hikichi, Y, Node, K (2005) Local release of C-reactive protein from vulnerable plaque or coronary arterial wall injured by stenting. In: J Am Coll Cardiol: United States, pp. 239-245.

Jackson, KA, Mi, T, Goodell, MA (1999) Hematopoietic potential of stem cells isolated from murine skeletal muscle. Proc Natl Acad Sci U S A 96: 14482-14486.

Jewell, UR, Kvietikova, I, Scheid, A, Bauer, C, Wenger, RH, Gassmann, M (2001) Induction of HIF-1alpha in response to hypoxia is instantaneous. FASEB J 15: 1312-1314.

Jujo, K, Ii, M, Losordo, DW (2008) Endothelial progenitor cells in neovascularization of infarcted myocardium. In: J Mol Cell Cardiol: England, pp. 530-544. 
Kabrun, N, Buhring, HJ, Choi, K, Ullrich, A, Risau, W, Keller, G (1997) Flk-1 expression defines a population of early embryonic hematopoietic precursors. Development 124: 2039-2048.

Kallianpur, AR, Jordan, JE, Brandt, SJ (1994) The SCL/TAL-1 gene is expressed in progenitors of both the hematopoietic and vascular systems during embryogenesis. Blood 83: 1200-1208.

Keck, PJ, Hauser, SD, Krivi, G, Sanzo, K, Warren, T, Feder, J, Connolly, DT (1989) Vascular permeability factor, an endothelial cell mitogen related to PDGF. Science 246: 13091312.

Keller, G, Kennedy, M, Papayannopoulou, T, Wiles, MV (1993) Hematopoietic commitment during embryonic stem cell differentiation in culture. Mol Cell Biol 13: 473-486.

Keller, GM (1995) In vitro differentiation of embryonic stem cells. In: Curr Opin Cell Biol: United States, pp. 862-869.

Kennedy, M, Firpo, M, Choi, K, Wall, C, Robertson, S, Kabrun, N, Keller, G (1997) A common precursor for primitive erythropoiesis and definitive haematopoiesis. Nature 386: 488-493.

Kocher, AA, Schuster, MD, Szabolcs, MJ, Takuma, S, Burkhoff, D, Wang, J, Homma, S, Edwards, NM, Itescu, S (2001) Neovascularization of ischemic myocardium by human bone-marrow-derived angioblasts prevents cardiomyocyte apoptosis, reduces remodeling and improves cardiac function. In: Nat Med: United States, pp. 430-436.

Kondo, T, Hayashi, M, Takeshita, K, Numaguchi, Y, Kobayashi, K, Iino, S, Inden, Y, Murohara, T (2004) Smoking cessation rapidly increases circulating progenitor cells in peripheral blood in chronic smokers. In: Arterioscler Thromb Vasc Biol: United States, pp. 1442-1447.

Krause, DS, Theise, ND, Collector, MI, Henegariu, O, Hwang, S, Gardner, R, Neutzel, S, Sharkis, SJ (2001) Multi-organ, multi-lineage engraftment by a single bone marrowderived stem cell. In: Cell: United States, pp. 369-377.

Kumar, V, Abbas, AK, Fausto, N, Aster, J (2011) Robbins and Cotran Pathologic Basis of Disease.

Kunz, J, Schreiter, B, Schubert, B, Voss, K, Krieg, K (1978) [Experimental investigations on the regeneration of aortic endothelial cells. Automatic and visual evaluation of autoradiograms (author's transl)]. Acta Histochem 61: 53-63.

Kushner, I, Samols, D, Magrey, M (2010) A unifying biologic explanation for "highsensitivity" C-reactive protein and "low-grade" inflammation. Arthritis Care Res (Hoboken) 62: 442-446.

Lagasse, E, Connors, H, Al-Dhalimy, M, Reitsma, M, Dohse, M, Osborne, L, Wang, X, Finegold, M, Weissman, IL, Grompe, M (2000) Purified hematopoietic stem cells can differentiate into hepatocytes in vivo. Nat Med 6: 1229-1234.

Langer, H, May, AE, Daub, K, Heinzmann, U, Lang, P, Schumm, M, Vestweber, D, Massberg, S, Schonberger, T, Pfisterer, I, Hatzopoulos, AK, Gawaz, M (2006) Adherent platelets recruit and induce differentiation of murine embryonic endothelial progenitor cells to mature endothelial cells in vitro. In: Circ Res: United States, pp. e2-10. 
Laufs, U, Werner, N, Link, A, Endres, M, Wassmann, S, Jurgens, K, Miche, E, Bohm, M, Nickenig, G (2004) Physical training increases endothelial progenitor cells, inhibits neointima formation, and enhances angiogenesis. In: Circulation: United States, pp. 220-226.

Lee, S, Chen, TT, Barber, CL, Jordan, MC, Murdock, J, Desai, S, Ferrara, N, Nagy, A, Roos, $\mathrm{KP}$, Iruela-Arispe, ML (2007) Autocrine VEGF signaling is required for vascular homeostasis. In: Cell: United States, pp. 691-703.

Leung, DW, Cachianes, G, Kuang, WJ, Goeddel, DV, Ferrara, N (1989) Vascular endothelial growth factor is a secreted angiogenic mitogen. Science 246: 1306-1309.

Li, JJ, Fang, CH (2004) C-reactive protein is not only an inflammatory marker but also a direct cause of cardiovascular diseases. In: Med Hypotheses: Scotland, pp. 499-506.

Lin, Y, Weisdorf, DJ, Solovey, A, Hebbel, RP (2000) Origins of circulating endothelial cells and endothelial outgrowth from blood. J Clin Invest 105: 71-77.

Lu, D, Kassab, GS (2011) Role of shear stress and stretch in vascular mechanobiology. In: J R Soc Interface.

Malczak, HT, Buck, RC (1977) Regeneration of endothelium in rat aorta after local freezing. A scanning electron microscopic study. Am J Pathol 86: 133-148.

Mancuso, P, Burlini, A, Pruneri, G, Goldhirsch, A, Martinelli, G, Bertolini, F (2001) Resting and activated endothelial cells are increased in the peripheral blood of cancer patients. Blood 97: 3658-3661.

Massa, M, Campanelli, R, Bonetti, E, Ferrario, M, Marinoni, B, Rosti, V (2009) Rapid and large increase of the frequency of circulating endothelial colony-forming cells (ECFCs) generating late outgrowth endothelial cells in patients with acute myocardial infarction. In: Exp Hematol: Netherlands, pp. 8-9.

Mezey, E, Chandross, KJ, Harta, G, Maki, RA, McKercher, SR (2000) Turning blood into brain: cells bearing neuronal antigens generated in vivo from bone marrow. In: Science: United States, pp. 1779-1782.

Mikirova, NA, Jackson, JA, Hunninghake, R, Kenyon, J, Chan, KW, Swindlehurst, CA, Minev, B, Patel, AN, Murphy, MP, Smith, L, Alexandrescu, DT, Ichim, TE, Riordan, $\mathrm{NH}$ (2009) Circulating endothelial progenitor cells: a new approach to anti-aging medicine? In: J Transl Med: England, p. 106.

Millauer, B, Wizigmann-Voos, S, Schnurch, H, Martinez, R, Moller, NP, Risau, W, Ullrich, A (1993) High affinity VEGF binding and developmental expression suggest Flk-1 as a major regulator of vasculogenesis and angiogenesis. In: Cell: United States, pp. 835-846.

Mor, F, Quintana, FJ, Cohen, IR (2004) Angiogenesis-inflammation cross-talk: vascular endothelial growth factor is secreted by activated $\mathrm{T}$ cells and induces Th1 polarization. J Immunol 172: 4618-4623.

Murray, PDF (1932) The Development in vitro of the Blood of the Early Chick Embryo. Proceedings of the Royal Society of London, pp. 497-521.

Mutunga, M, Fulton, B, Bullock, R, Batchelor, A, Gascoigne, A, Gillespie, JI, Baudouin, SV (2001) Circulating endothelial cells in patients with septic shock. Am J Respir Crit Care Med 163: 195-200. 
Nakano, T, Kodama, H, Honjo, T (1994) Generation of lymphohematopoietic cells from embryonic stem cells in culture. Science 265: 1098-1101.

Nakatani, K, Takeshita, S, Tsujimoto, H, Kawamura, Y, Tokutomi, T, Sekine, I (2003) Circulating endothelial cells in Kawasaki disease. In: Clin Exp Immunol: England, pp. 536-540.

Naldini, A, Carraro, F (2005) Role of inflammatory mediators in angiogenesis. Curr Drug Targets Inflamm Allergy 4: 3-8.

Nolan, DJ, Ciarrocchi, A, Mellick, AS, Jaggi, JS, Bambino, K, Gupta, S, Heikamp, E, McDevitt, MR, Scheinberg, DA, Benezra, R, Mittal, V (2007) Bone marrow-derived endothelial progenitor cells are a major determinant of nascent tumor neovascularization. In: Genes Dev: United States, pp. 1546-1558.

Noonan, DM, De Lerma Barbaro, A, Vannini, N, Mortara, L, Albini, A (2008) Inflammation, inflammatory cells and angiogenesis: decisions and indecisions. Cancer Metastasis Rev 27: 31-40.

Olsson, AK, Dimberg, A, Kreuger, J, Claesson-Welsh, L (2006) VEGF receptor signalling - in control of vascular function. In: Nat Rev Mol Cell Biol: England, pp. 359-371.

Paoletti, R, Gotto, AM, Jr., Hajjar, DP (2004) Inflammation in atherosclerosis and implications for therapy. In: Circulation: United States, pp. III20-26.

Peichev, M, Naiyer, AJ, Pereira, D, Zhu, Z, Lane, WJ, Williams, M, Oz, MC, Hicklin, DJ, Witte, L, Moore, MA, Rafii, S (2000) Expression of VEGFR-2 and AC133 by circulating human CD34(+) cells identifies a population of functional endothelial precursors. Blood 95: 952-958.

Plouet, J, Schilling, J, Gospodarowicz, D (1989) Isolation and characterization of a newly identified endothelial cell mitogen produced by AtT-20 cells. EMBO J 8: 3801-3806.

Purhonen, S, Palm, J, Rossi, D, Kaskenpaa, N, Rajantie, I, Yla-Herttuala, S, Alitalo, K, Weissman, IL, Salven, P (2008) Bone marrow-derived circulating endothelial precursors do not contribute to vascular endothelium and are not needed for tumor growth. In: Proc Natl Acad Sci U S A: United States, pp. 6620-6625.

Rajashekhar, G, Willuweit, A, Patterson, CE, Sun, P, Hilbig, A, Breier, G, Helisch, A, Clauss, $M$ (2006) Continuous endothelial cell activation increases angiogenesis: evidence for the direct role of endothelium linking angiogenesis and inflammation. In: J Vasc Res: Switzerland, pp. 193-204.

Ratcliffe, NA, Rowley, AF (1979) A comparative synopsis of the structure and function of the blood cells of insects and other invertebrates. Dev Comp Immunol 3: 189-221.

Rehman, J, Li, J, Orschell, CM, March, KL (2003) Peripheral blood "endothelial progenitor cells" are derived from monocyte/macrophages and secrete angiogenic growth factors. Circulation 107: 1164-1169.

Rehman, J, Li, J, Parvathaneni, L, Karlsson, G, Panchal, VR, Temm, CJ, Mahenthiran, J, March, KL (2004) Exercise acutely increases circulating endothelial progenitor cells and monocyte-/macrophage-derived angiogenic cells. In: J Am Coll Cardiol: United States, pp. 2314-2318.

Reyes, M, Dudek, A, Jahagirdar, B, Koodie, L, Marker, PH, Verfaillie, CM (2002) Origin of endothelial progenitors in human postnatal bone marrow. J Clin Invest 109: 337-346. 
Ridker, PM (2001) High-sensitivity C-reactive protein: potential adjunct for global risk assessment in the primary prevention of cardiovascular disease. Circulation 103: 1813-1818.

Risau, W, Flamme, I (1995) Vasculogenesis. Annu Rev Cell Dev Biol 11: 73-91.

Risau, W, Sariola, H, Zerwes, HG, Sasse, J, Ekblom, P, Kemler, R, Doetschman, T (1988) Vasculogenesis and angiogenesis in embryonic-stem-cell-derived embryoid bodies. Development 102: 471-478.

Ruppert, EE, Carle, KJ (1983) Morphology of metazoan circulatory systems. 193-208.

Sabin, FR (1920) Studies on the origin of blood vessels and of red corpuscles as seen in the living blastoderm of the chick during the second day of incubation. Contribution to Emmbryology, pp. 231-262.

Sandri, M, Adams, V, Gielen, S, Linke, A, Lenk, K, Krankel, N, Lenz, D, Erbs, S, Scheinert, D, Mohr, FW, Schuler, G, Hambrecht, R (2005) Effects of exercise and ischemia on mobilization and functional activation of blood-derived progenitor cells in patients with ischemic syndromes: results of 3 randomized studies. In: Circulation: United States, pp. 3391-3399.

Sandri, M, Beck, EB, Adams, V, Gielen, S, Lenk, K, Hollriegel, R, Mangner, N, Linke, A, Erbs, S, Mobius-Winkler, S, Scheinert, D, Hambrecht, R, Schuler, G (2011) Maximal exercise, limb ischemia, and endothelial progenitor cells. Eur J Cardiovasc Prev Rehabil 18: 55-64.

Scadden, DT (2007) The weight of cell identity. J Clin Invest 117: 3653-3655.

Schabbauer, G, Schweighofer, B, Mechtcheriakova, D, Lucerna, M, Binder, BR, Hofer, E (2007) Nuclear factor of activated T cells and early growth response-1 cooperate to mediate tissue factor gene induction by vascular endothelial growth factor in endothelial cells. In: Thromb Haemost: Germany, pp. 988-997.

Schlaeger, TM, Bartunkova, S, Lawitts, JA, Teichmann, G, Risau, W, Deutsch, U, Sato, TN (1997) Uniform vascular-endothelial-cell-specific gene expression in both embryonic and adult transgenic mice. Proc Natl Acad Sci U S A 94: 3058-3063.

Schobersberger, W, Leichtfried, V, Mueck-Weymann, M, Humpeler, E (2010) Austrian Moderate Altitude Studies (AMAS): benefits of exposure to moderate altitudes (1,500-2,500 m). Sleep Breath 14: 201-207.

Schroder, K, Kohnen, A, Aicher, A, Liehn, EA, Buchse, T, Stein, S, Weber, C, Dimmeler, S, Brandes, RP (2009) NADPH oxidase Nox2 is required for hypoxia-induced mobilization of endothelial progenitor cells. In: Circ Res: United States, pp. 537-544.

Schroder, K, Schutz, S, Schloffel, I, Batz, S, Takac, I, Weissmann, N, Michaelis, UR, Koyanagi, M, Brandes, RP (2010) Hepatocyte growth factor induces a proangiogenic phenotype and mobilizes endothelial progenitor cells by activating Nox2. Antioxid Redox Signal.

Schwartz, SM, Gajdusek, CM, Reidy, MA, Selden, SC, 3rd, Haudenschild, CC (1980) Maintenance of integrity in aortic endothelium. Fed Proc 39: 2618-2625.

Schwartz, SM, Gajdusek, CM, Selden, SC, 3rd (1981) Vascular wall growth control: the role of the endothelium. Arteriosclerosis 1: 107-126.

Schwartz, SM, Stemerman, MB, Benditt, EP (1975) The aortic intima. II. Repair of the aortic lining after mechanical denudation. Am J Pathol 81: 15-42. 
Schwedler, SB, Filep, JG, Galle, J, Wanner, C, Potempa, LA (2006) C-reactive protein: a family of proteins to regulate cardiovascular function. In: Am J Kidney Dis: United States, pp. 212-222.

Schweighofer, B, Schultes, J, Pomyje, J, Hofer, E (2007) Signals and genes induced by angiogenic growth factors in comparison to inflammatory cytokines in endothelial cells. Clin Hemorheol Microcirc 37: 57-62.

Senger, DR, Galli, SJ, Dvorak, AM, Perruzzi, CA, Harvey, VS, Dvorak, HF (1983) Tumor cells secrete a vascular permeability factor that promotes accumulation of ascites fluid. Science 219: 983-985.

Shaffer, RG, Greene, S, Arshi, A, Supple, G, Bantly, A, Moore, JS, Parmacek, MS, Mohler, ER, 3rd (2006) Effect of acute exercise on endothelial progenitor cells in patients with peripheral arterial disease. Vasc Med 11: 219-226.

Shalaby, F, Ho, J, Stanford, WL, Fischer, KD, Schuh, AC, Schwartz, L, Bernstein, A, Rossant, J (1997) A requirement for Flk1 in primitive and definitive hematopoiesis and vasculogenesis. In: Cell: United States, pp. 981-990.

Shalaby, F, Rossant, J, Yamaguchi, TP, Gertsenstein, M, Wu, XF, Breitman, ML, Schuh, AC (1995) Failure of blood-island formation and vasculogenesis in Flk-1-deficient mice. Nature 376: 62-66.

Shen, L, Gao, Y, Qian, J, Sun, A, Ge, J (2011) A novel mechanism for endothelial progenitor cells homing: The SDF-1/CXCR4-Rac pathway may regulate endothelial progenitor cells homing through cellular polarization. In: Med Hypotheses, A 2010 Elsevier Ltd: United States, pp. 256-258.

Shi, Q, Rafii, S, Wu, MH, Wijelath, ES, Yu, C, Ishida, A, Fujita, Y, Kothari, S, Mohle, R, Sauvage, LR, Moore, MA, Storb, RF, Hammond, WP (1998) Evidence for circulating bone marrow-derived endothelial cells. Blood 92: 362-367.

Shintani, S, Murohara, T, Ikeda, H, Ueno, T, Honma, T, Katoh, A, Sasaki, K, Shimada, T, Oike, Y, Imaizumi, T (2001) Mobilization of endothelial progenitor cells in patients with acute myocardial infarction. Circulation 103: 2776-2779.

Slevin, M, Krupinski, J (2009) A role for monomeric C-reactive protein in regulation of angiogenesis, endothelial cell inflammation and thrombus formation in cardiovascular/cerebrovascular disease? Histol Histopathol 24: 1473-1478.

Slevin, M, Matou-Nasri, S, Turu, M, Luque, A, Rovira, N, Badimon, L, Boluda, S, Potempa, L, Sanfeliu, C, de Vera, N, Krupinski, J (2010) Modified C-reactive protein is expressed by stroke neovessels and is a potent activator of angiogenesis in vitro. In: Brain Pathol: Switzerland, pp. 151-165.

Sobrino, T, Hurtado, O, Moro, MA, Rodriguez-Yanez, M, Castellanos, M, Brea, D, Moldes, O, Blanco, M, Arenillas, JF, Leira, R, Davalos, A, Lizasoain, I, Castillo, J (2007) The increase of circulating endothelial progenitor cells after acute ischemic stroke is associated with good outcome. In: Stroke: United States, pp. 2759-2764.

Sprague, AH, Khalil, RA (2009) Inflammatory cytokines in vascular dysfunction and vascular disease. In: Biochem Pharmacol: England, pp. 539-552.

Studer, L, Csete, M, Lee, SH, Kabbani, N, Walikonis, J, Wold, B, McKay, R (2000) Enhanced proliferation, survival, and dopaminergic differentiation of CNS precursors in lowered oxygen. J Neurosci 20: 7377-7383. 
Takahashi, T, Kalka, C, Masuda, H, Chen, D, Silver, M, Kearney, M, Magner, M, Isner, JM, Asahara, T (1999) Ischemia- and cytokine-induced mobilization of bone marrow-derived endothelial progenitor cells for neovascularization. Nat Med 5: 434-438.

Taylor, RG, Lewis, JC (1986) Endothelial cell proliferation and monocyte adhesion to atherosclerotic lesions of white carneau pigeons. Am J Pathol 125: 152-160.

Tepper, OM, Capla, JM, Galiano, RD, Ceradini, DJ, Callaghan, MJ, Kleinman, ME, Gurtner, GC (2005) Adult vasculogenesis occurs through in situ recruitment, proliferation, and tubulization of circulating bone marrow-derived cells. In: Blood: United States, pp. 1068-1077.

Timmermans, F, Plum, J, Yoder, MC, Ingram, DA, Vandekerckhove, B, Case, J (2009) Endothelial progenitor cells: identity defined? In: J Cell Mol Med: England, pp. 87102.

Timmermans, F, Van Hauwermeiren, F, De Smedt, M, Raedt, R, Plasschaert, F, De Buyzere, ML, Gillebert, TC, Plum, J, Vandekerckhove, B (2007) Endothelial outgrowth cells are not derived from $\mathrm{CD} 133+$ cells or $\mathrm{CD} 45+$ hematopoietic precursors. In: Arterioscler Thromb Vasc Biol: United States, pp. 1572-1579.

Tongers, J, Roncalli, JG, Losordo, DW (2010) Role of endothelial progenitor cells during ischemia-induced vasculogenesis and collateral formation. In: Microvasc Res, 2010 Elsevier Inc: United States, pp. 200-206.

Torsney, E, Xu, Q (2011) Resident vascular progenitor cells. In: J Mol Cell Cardiol, 2010 Elsevier Ltd: England, pp. 304-311.

Turu, MM, Slevin, M, Matou, S, West, D, Rodriguez, C, Luque, A, Grau-Olivares, M, Badimon, L, Martinez-Gonzalez, J, Krupinski, J (2008) C-reactive protein exerts angiogenic effects on vascular endothelial cells and modulates associated signalling pathways and gene expression. In: BMC Cell Biol: England, p. 47.

Urao, N, Okigaki, M, Yamada, H, Aadachi, Y, Matsuno, K, Matsui, A, Matsunaga, S, Tateishi, K, Nomura, T, Takahashi, T, Tatsumi, T, Matsubara, H (2006) Erythropoietin-mobilized endothelial progenitors enhance reendothelialization via Akt-endothelial nitric oxide synthase activation and prevent neointimal hyperplasia. In: Circ Res: United States, pp. 1405-1413.

Urbich C, Heeschen C, Aicher A, Dernbach E, Zeiher AM, Dimmeler S (2003) Relevance of monocytic features for neovascularization capacity of circulating endothelial progenitor cells. Circulation 2003 18;108(20):2511-6.

Venugopal, SK, Devaraj, S, Jialal, I (2005) Macrophage conditioned medium induces the expression of C-reactive protein in human aortic endothelial cells: potential for paracrine/autocrine effects. In: Am J Pathol: United States, pp. 1265-1271.

Verma, S, Kuliszewski, MA, Li, SH, Szmitko, PE, Zucco, L, Wang, CH, Badiwala, MV, Mickle, DA, Weisel, RD, Fedak, PW, Stewart, DJ, Kutryk, MJ (2004) C-reactive protein attenuates endothelial progenitor cell survival, differentiation, and function: further evidence of a mechanistic link between C-reactive protein and cardiovascular disease. In: Circulation: United States, pp. 2058-2067. 
Vittet, D, Prandini, MH, Berthier, R, Schweitzer, A, Martin-Sisteron, H, Uzan, G, Dejana, E (1996) Embryonic stem cells differentiate in vitro to endothelial cells through successive maturation steps. Blood 88: 3424-3431.

Wagner, R (1980) Endothelial cell embryology and growth. Adv. Microcirc., p. 45.

Walter, DH, Haendeler, J, Reinhold, J, Rochwalsky, U, Seeger, F, Honold, J, Hoffmann, J, Urbich, C, Lehmann, R, Arenzana-Seisdesdos, F, Aicher, A, Heeschen, C, Fichtlscherer, S, Zeiher, AM, Dimmeler, S (2005) Impaired CXCR4 signaling contributes to the reduced neovascularization capacity of endothelial progenitor cells from patients with coronary artery disease. In: Circ Res: United States, pp. 1142-1151.

Wang, DH, Li, FR, Zhang, Y, Wang, YQ, Yuan, FH (2010) Conditioned medium from renal tubular epithelial cells stimulated by hypoxia influences rat bone marrow-derived endothelial progenitor cells. Ren Fail 32: 863-870.

Weiss, MJ, Orkin, SH (1996) In vitro differentiation of murine embryonic stem cells. New approaches to old problems. J Clin Invest 97: 591-595.

Wiles, MV, Keller, G (1991) Multiple hematopoietic lineages develop from embryonic stem (ES) cells in culture. Development 111: 259-267.

Winsauer, G, de Martin, R (2007) Resolution of inflammation: intracellular feedback loops in the endothelium. In: Thromb Haemost: Germany, pp. 364-369.

Wojakowski, W, Tendera, M, Michalowska, A, Majka, M, Kucia, M, Maslankiewicz, K, Wyderka, R, Ochala, A, Ratajczak, MZ (2004) Mobilization of CD34/CXCR4+, CD34/CD117+, c-met+ stem cells, and mononuclear cells expressing early cardiac, muscle, and endothelial markers into peripheral blood in patients with acute myocardial infarction. In: Circulation: United States, pp. 3213-3220.

Yamaguchi, TP, Dumont, DJ, Conlon, RA, Breitman, ML, Rossant, J (1993) flk-1, an fltrelated receptor tyrosine kinase is an early marker for endothelial cell precursors. Development 118: 489-498.

Ye, C, Bai, L, Yan, ZQ, Wang, YH, Jiang, ZL (2008) Shear stress and vascular smooth muscle cells promote endothelial differentiation of endothelial progenitor cells via activation of Akt. In: Clin Biomech (Bristol, Avon): England, pp. S118-124.

Yip, HK, Chang, LT, Chang, WN, Lu, CH, Liou, CW, Lan, MY, Liu, JS, Youssef, AA, Chang, HW (2008) Level and value of circulating endothelial progenitor cells in patients after acute ischemic stroke. In: Stroke: United States, pp. 69-74.

Yoder, MC, Mead, LE, Prater, D, Krier, TR, Mroueh, KN, Li, F, Krasich, R, Temm, CJ, Prchal, JT, Ingram, DA (2007) Redefining endothelial progenitor cells via clonal analysis and hematopoietic stem/progenitor cell principals. In: Blood: United States, pp. 1801-1809.

Young, PE, Baumhueter, S, Lasky, LA (1995) The sialomucin CD34 is expressed on hematopoietic cells and blood vessels during murine development. Blood 85: 96-105.

Zhang, QW, Liu, HJ, Duan, HF, Ha, XQ, Wang, H, Jia, XX, Lu, ZZ, Wu, CT, Wang, LS (2005) [Hepatocyte growth factor recruits endothelial progenitor cells from bone marrow into blood circulation]. Zhongguo Ying Yong Sheng Li Xue Za Zhi 21: 100-103. 
Zhu, G, Huang, L, Song, M, Yu, Z, Wu, X, Zhao, X, Jin, J, Zhao, G, Chen, J, Yu, S (2010) Overexpression of hepatocyte growth factor in smooth muscle cells regulates endothelial progenitor cells differentiation, migration and proliferation. In: Int J Cardiol: Netherlands, pp. 70-80. 


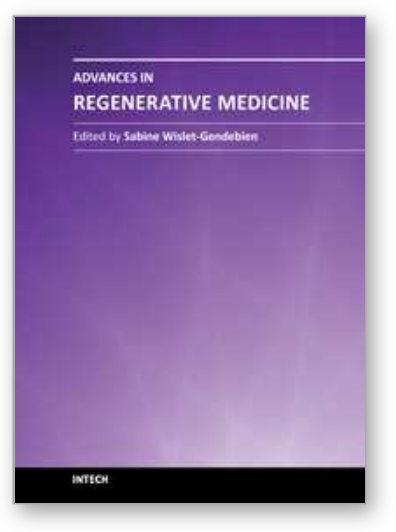

\author{
Advances in Regenerative Medicine \\ Edited by Dr Sabine Wislet-Gendebien
}

ISBN 978-953-307-732-1

Hard cover, 404 pages

Publisher InTech

Published online 21, November, 2011

Published in print edition November, 2011

Even if the origins of regenerative medicine can be found in Greek mythology, as attested by the story of Prometheus, the Greek god whose immortal liver was feasted on day after day by Zeus' eagle; many challenges persist in order to successfully regenerate lost cells, tissues or organs and rebuild all connections and functions. In this book, we will cover a few aspects of regenerative medicine highlighting major advances and remaining challenges in cellular therapy and tissue/organ engineering.

\title{
How to reference
}

In order to correctly reference this scholarly work, feel free to copy and paste the following:

Michele M. Ciulla, Paola Nicolini, Gianluca L. Perrucci, Chiara Benfenati and Fabio Magrini (2011). Inflammation-Angiogenesis Cross-Talk and Endothelial Progenitor Cells: A Crucial Axis in Regenerating Vessels, Advances in Regenerative Medicine, Dr Sabine Wislet-Gendebien (Ed.), ISBN: 978-953-307-732-1, InTech, Available from: http://www.intechopen.com/books/advances-in-regenerative-medicine/inflammationangiogenesis-cross-talk-and-endothelial-progenitor-cells-a-crucial-axis-in-regenerating

\section{INTECH}

open science | open minds

\section{InTech Europe}

University Campus STeP Ri

Slavka Krautzeka 83/A

51000 Rijeka, Croatia

Phone: +385 (51) 770447

Fax: +385 (51) 686166

www.intechopen.com

\section{InTech China}

Unit 405, Office Block, Hotel Equatorial Shanghai

No.65, Yan An Road (West), Shanghai, 200040, China

中国上海市延安西路65号上海国际贵都大饭店办公楼 405 单元

Phone: +86-21-62489820

Fax: +86-21-62489821 
(C) 2011 The Author(s). Licensee IntechOpen. This is an open access article distributed under the terms of the Creative Commons Attribution 3.0 License, which permits unrestricted use, distribution, and reproduction in any medium, provided the original work is properly cited. 